\title{
Knockdown of Hepatic Gonadotropin-Releasing Hormone by Vivo-Morpholino Decreases Liver Fibrosis in Multidrug Resistance Gene 2 Knockout Mice by Down-Regulation of miR-200b
}

\author{
Konstantina Kyritsi, ${ }^{*}$ Fanyin Meng, ${ }^{* \dagger \$ \$}$ Tianhao Zhou, ${ }^{*}$ Nan Wu, ${ }^{*}$ Julie Venter, ${ }^{*}$ Heather Francis, ${ }^{* \dagger}$ Lindsey Kennedy, ${ }^{*}$ \\ Paolo Onori, "Antonio Franchitto, ${ }^{\text {, }}$ Francesca Bernuzzi, ${ }^{* *}$ Pietro Invernizzi, ${ }^{* *}$ Kelly McDaniel, ${ }^{\S}$ Romina Mancinelli, \\ Domenico Alvaro, ${ }^{\dagger \dagger}$ Eugenio Gaudio, Gianfranco Alpini, ${ }^{* \dagger \ddagger}$ and Shannon Glaser ${ }^{* \dagger \dagger}$
}

\begin{abstract}
From the Department of Internal Medicine, ${ }^{*}$ Texas A\&M Health Science Center, College of Medicine, Temple, Texas; the Department of Research ${ }^{\dagger}$ Central Texas Veterans Health Care System, Temple, Texas; the Baylor Scott \& White Health Digestive Disease Research Center, ${ }^{\ddagger}$ Temple, Texas; the Research Foundation, ${ }^{\S}$ Baylor Scott \& White Health, Temple, Texas; the Department of Anatomical, Histological, Forensic Medicine and Orthopedics Sciences, ${ }^{\circ}$ Sapienza University of Rome, Rome, Italy; Eleonora Lorillard Spencer Cenci Foundation, ${ }^{\|}$Rome, Italy; Center for Autoimmune Liver Diseases, ** Humanitas Clinical and Research Center, Rozzano, Italy; and the Department of Medicine and Medical Specialties, ${ }^{\dagger \dagger}$ Sapienza University of Rome, Rome, Italy
\end{abstract}

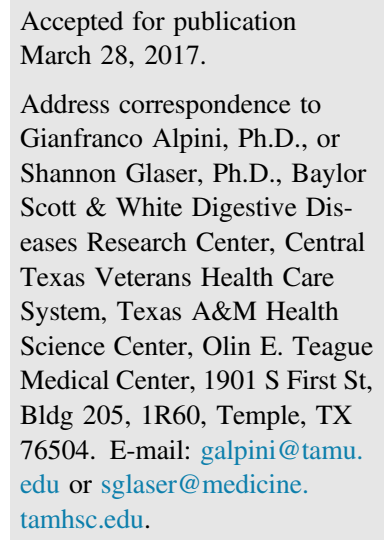

\begin{abstract}
Hepatic fibrosis occurs during the progression of primary sclerosing cholangitis (PSC) and is characterized by accumulation of extracellular matrix proteins. Proliferating cholangiocytes and activated hepatic stellate cells (HSCs) participate in the promotion of liver fibrosis during cholestasis. Gonadotropin-releasing hormone $(\mathrm{GnRH})$ is a trophic peptide hormone synthesized by hypothalamic neurons and the biliary epithelium and exerts its biological effects on cholangiocytes by interaction with the receptor subtype $\left(\mathrm{GnRHR}_{1}\right)$ expressed by cholangiocytes and HSCs. Previously, we demonstrated that administration of GnRH to normal rats increased intrahepatic biliary mass (IBDM) and hepatic fibrosis. Also, miR-200b is associated with the progression of hepatic fibrosis; however, the role of the GnRH/ $\mathrm{GnRHR}_{1} / \mathrm{miR}-200 \mathrm{~b}$ axis in the development of hepatic fibrosis in PSC is unknown. Herein, using the mouse model of PSC (multidrug resistance gene 2 knockout), the hepatic knockdown of GnRH decreased IBDM and liver fibrosis. In vivo and in vitro administration of $\mathrm{GnRH}$ increased the expression of miR-200b and fibrosis markers. The GnRH/GnRHR 1 axis and miR-200b were up-regulated in human PSC samples. Cetrorelix, a GnRHR $R_{1}$ antagonist, inhibited the expression of fibrotic genes in vitro and decreased IBDM and hepatic fibrosis in vivo. Inhibition of miR-200b decreased the expression of fibrosis genes in vitro in cholangiocyte and HSC lines. Targeting the GnRH/GnRHR 1 /miR-200b axis may be key for the management of hepatic fibrosis during the progression of PSC. (Am J Pathol 2017, 187: 1551-1565; http:// dx.doi.org/10.1016/j.ajpath.2017.03.013)
\end{abstract}

\footnotetext{
Supported by the Dr. Nicholas C. Hightower Centennial Chair of Gastroenterology from Baylor Scott \& White, a VA Research Senior Career Scientist Award, Veterans Affairs Merit awards 5I01BX000574 (G.F.), 5I01BX002192 (S.G.) 1I01BX001724 (F.M.) and 1I01BX003031 (H.F.), University of Rome La Sapienza, Funds for Investment in Basic Research Accordi di Programma 2010 RBAP10Z7FS (E.G.), and NIH grants DK054811, DK076898, and DK062975 (G.A., F.M., and S.G.) and DK108959 (H.F.). This material is the result of work supported by resources at the Central Texas Veterans Health Care System.
}

K.K. and F.M. contributed equally to this work.

E.G., G.A., and S.G. contributed equally to this work as senior authors. Disclosures: None declared.

The content is the responsibility of the author(s) alone and does not necessarily reflect the views or policies of the Department of Veterans Affairs or the US Government.

Current address of F.B. and P.I., Program for Autoimmune Liver Diseases, Department of Medicine and Surgery, University of Milan-Bicocca, Milan, Italy. 
In addition to secretion of water and electrolytes to modify the composition of ductal bile before it reaches the duodenum, cholangiocytes are the target cells of a number of cholangiopathies, including primary sclerosing cholangitis (PSC) and primary biliary cholangitis. ${ }^{1,2}$ A number of neuroendocrine factors regulate the homeostasis of the biliary epithelium through changes in the balance between biliary proliferation and apoptosis (hallmarks of cholangiopathies), leading to changes in liver fibrosis. ${ }^{3-7}$ PSC is a chronic disease that affects the biliary epithelium, causing biliary proliferation, inflammation, fibrosis, liver cirrhosis, and ultimately death. ${ }^{1,2,7}$ Therapy for the management of PSC is currently lacking because of the poor knowledge of the pathogenesis of this disease; therefore, studies aimed to better understand the molecular mechanisms underlying PSC pathogenesis are necessary. The multidrug resistance gene 2 knockout $\left(\mathrm{Mdr} 2^{-1-}\right.$; official gene name $\left.A b c b 4\right)$ mouse model is widely used for studying the mechanisms of the pathogenesis and management of PSC. ${ }^{4,8-10}$ The $\mathrm{Mdr} 2^{-1-}$ mouse serves as a genetic model of progressive PSC coupled with biliary fibrosis. ${ }^{4,8,9}$

The peptide gonadotropin-releasing hormone $(\mathrm{GnRH}$; ie, synthesized and released from neurons within the hypo-

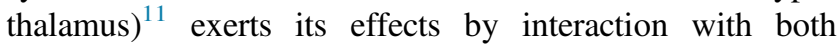
receptor subtypes, $\mathrm{GnRHR}_{1}$ and $\mathrm{GnRHR}_{2}$, that are also expressed in peripheral organs, such as pancreas, colon, and liver. ${ }^{12,13}$ We have previously shown that GnRH induces biliary hyperplasia in normal and cholestatic bile duct-ligated rats by both paracrine/autocrine mechanisms by a specific interaction with the receptor subtype, $\mathrm{GnRHR}_{1} \cdot{ }^{14}$ Supporting the selective role of $\mathrm{GnRHR}_{1}$ on biliary functions, in mammals $\mathrm{GnRHR}_{2}$ transcription occurs but it does not produce a functional C-terminal multitransmembrane protein. ${ }^{15}$ No data exist regarding the role of the GnRH/ GnRHR $_{1}$ axis in models of PSC and human PSC samples.

miRNAs are small noncoding RNA molecules that regulate a number of pathophysiological processes, including cell proliferation/apoptosis, stem cell differentiation, and the progression of cholestatic liver disease. ${ }^{16,17}$ miR-200 is a highly conserved family of miRNAs that regulate cellular proliferation and remodeling during liver injury, fibrosis, and hepatocellular carcinoma. ${ }^{18-21}$ The miR-200 family includes miR-200a, miR-200b, miR-200c, miR-141, and miR-429. A number of studies have demonstrated the role of miR-200b in the management of liver diseases, including cholangiopathies and hepatic fibrosis. $^{22-24}$ For example, one study has shown that miR-200b is overexpressed in malignant cholangiocytes and its inhibition increases sensitivity to chemotherapeutic agents, such as gemcitabine. ${ }^{22}$ Furthermore, miR-200b is up-regulated in patients with biliary atresia and accelerates the activation and migration of hepatic stellate cells (HSCs). ${ }^{24}$ Moreover, another study has demonstrated that the progression of liver fibrosis in humans and mice positively correlates with overexpression of the miR-200b. ${ }^{23}$ No information exists regarding the role of miR-200b in the modulation of biliary damage and liver fibrosis in PSC. On the basis of this background, we hypothesized that GnRH/ $\mathrm{GnRHR}_{1}$ stimulates biliary proliferation and liver fibrosis by both autocrine/paracrine pathways (by coordinately activating cholangiocytes and $\mathrm{HSCs}$ ) in $\mathrm{Mdr} 2^{-/-}$mice and human PSC through changes in miR-200b.

\section{Materials and Methods}

\section{Reagents}

Reagents were purchased from Sigma-Aldrich Co. (St. Louis, MO) unless otherwise indicated. The rat antibody against cytokeratin-19 (CK-19) was obtained from Developmental Studies Hybridoma Bank (Iowa City, IA). The rabbit synaptophysin, the goat monoclonal antibody against hepatocyte nuclear factor- $4 \alpha$, and the anti-desmin antibody (Y66; Alexa Fluor 488) were purchased from Abcam (Cambridge, MA). The rabbit antibodies for $\mathrm{GnRHR}_{1}$ and GnRH were purchased from Santa Cruz Biotechnology, Inc. (Dallas, TX). The Nova Ultra Sirius Red Stain kit to detect interstitial collagen deposition was purchased from IHC World (Woodstock, MD). The enzyme immunoassay kits to measure GnRH levels in supernatants from isolated cholangiocytes (after incubation for 4 hours at $37^{\circ} \mathrm{C}$ ) ${ }^{6}$ as well as serum from healthy control and early- and late-stage male

Table 1 Characteristics of Healthy Controls and PSC Patients

\begin{tabular}{lllllll}
\hline Groups & Patient no. & Diagnosis & Sex & Cirrhosis & Therapy & Origin \\
\hline Control & 1 & Normal liver & Male & & Untreated & BioChain (Newark, CA) \\
& 2 & Normal liver & Male & & Untreated & BioChain \\
& 3 & Normal liver & Male & & Untreated & BioChain \\
& 4 & Normal liver & Male & & Untreated & BioChain \\
PSC & 1 & Late-stage & Male & Yes & Untreated & Humanitas Research Hospital (Milan, Italy) \\
& 2 & PSC & & & & \\
& & Late-stage & Male & No & Untreated & Humanitas Research Hospital \\
& 3 & PSC & Mate-stage & No & Untreated & Humanitas Research Hospital \\
& & PSC & & & & \\
\hline
\end{tabular}

Unidentified human samples were obtained from Dr. Pietro Invernizzi (Humanitas Research Hospital, Rozzano, Italy).

PSC, primary sclerosing cholangitis. 
Table 2 Characteristics of Healthy Controls and Early- and Late-Stage PSC Patients

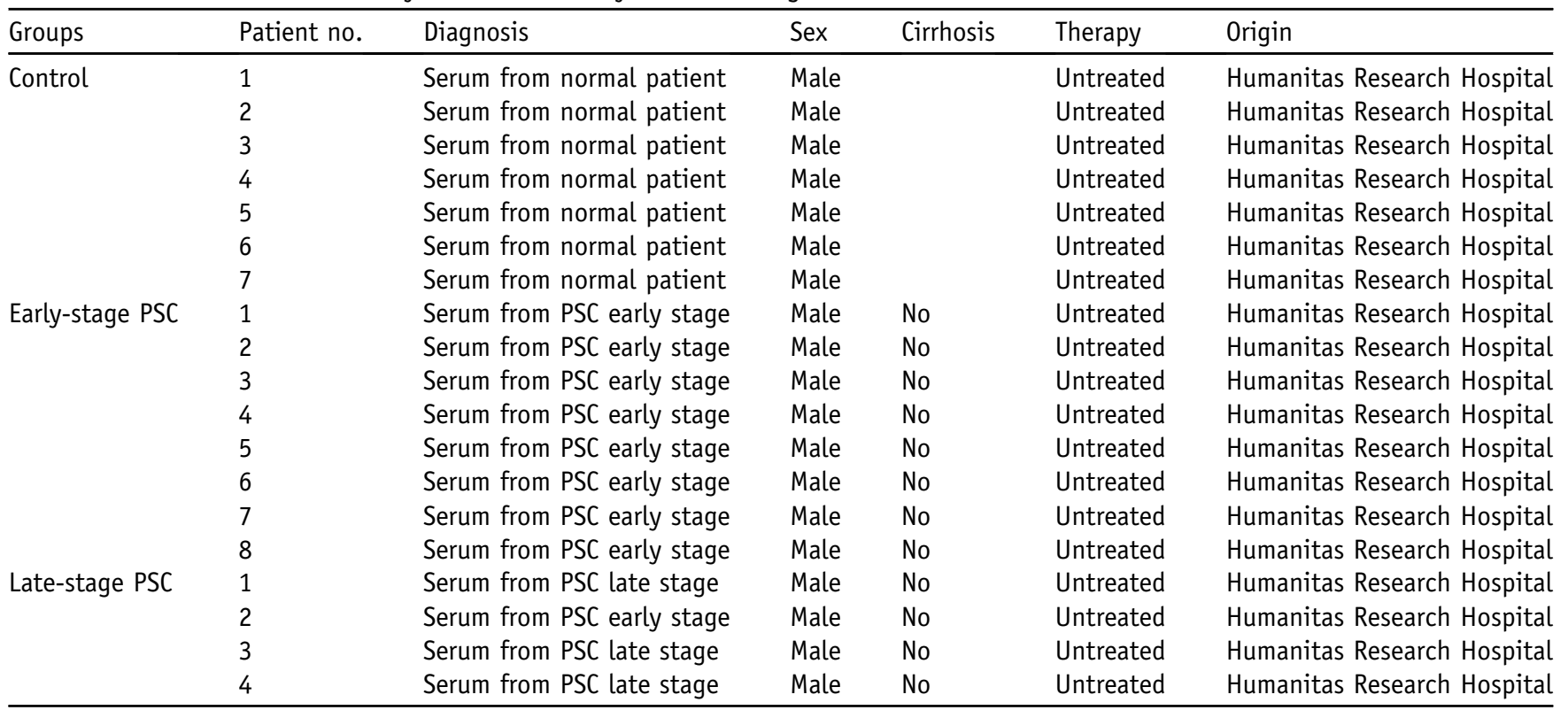

Unidentified human samples were obtained from Dr. Pietro Invernizzi (Humanitas Research Hospital, Rozzano, Italy).

PSC, primary sclerosing cholangitis.

PSC patients were purchased from Phoenix Pharmaceutical Inc. (Burlingame, CA). All real-time PCR primers and the RNeasy kit for the purification of total RNA and reagents for real-time PCRs were obtained from Qiagen (Valencia, CA). We used the following mouse primers: $\mathrm{GnRHR}_{1}$ (PPM04852B); GnRH (PPM57676A); proliferating cell nuclear antigen (PCNA; PPM03456F); Ki-67 (PPM03457B); transforming growth factor- $\beta 1$ (TGF- $\beta 1$; PPM02991B); TGF- $\beta 1$ receptor (TGF- $\beta 1 R$; PPM03072C);
Serpine1 (PPM03093C); glyceraldehyde-3-phosphate dehydrogenase (PPM02946E); and miRNA primers [miR-200b (4427975: assay002251) and U6 snRNA (4427975: assay 001973, housekeeping for miR-200b)]. For real-time PCR analysis in human hepatic stellate cell lines (HHSteCs), we used the following primers: TGF- $\beta 1$ (PPH00508A), TGF- $\beta 1 \mathrm{R}$ (PPH00237C), matrix metalloproteinase 9 (PPH00152E), Serpine1 (PPH00215F), and glyceraldehyde-3-phosphate dehydrogenase (PPH00150F).
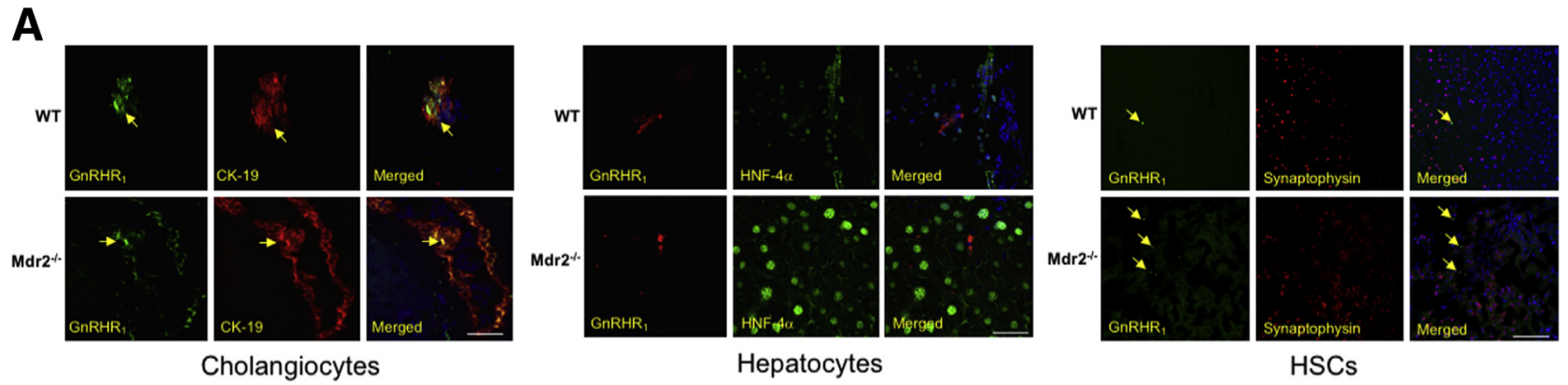

HSCs

B

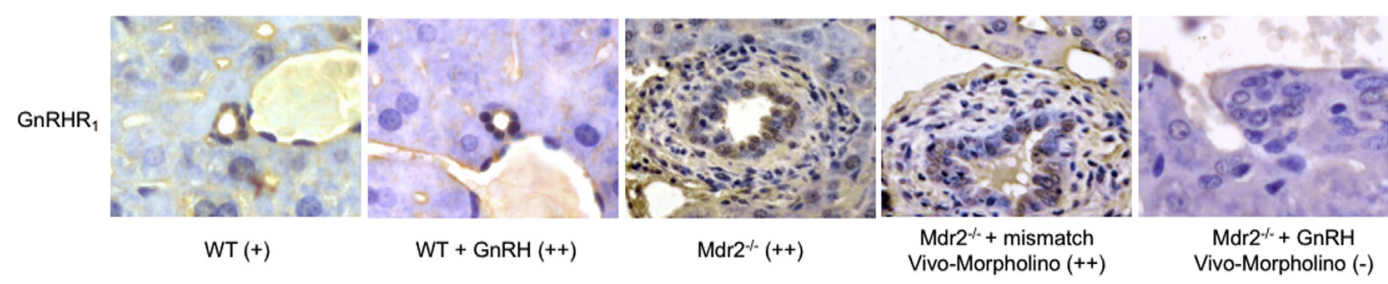

Figure 1 A: Intrahepatic cholangiocytes and HSCs express $G_{n R H R}$. Nuclei were stained with DAPI (blue). The immunoreactivity of GnRHR $R_{1}$ is absent in hepatocytes. Localization of $\mathrm{GnRHR}_{1}$ and CK-19 in bile ducts is indicated by arrows. B: There is enhanced immunoreactivity for GnRHR in cholangiocytes from WT mice treated with GnRH and Mdr2 ${ }^{-/-}$mice compared to WT mice. The expression of $\mathrm{GnRHR}_{1}$ decreases in cholangiocytes from Mdr2 ${ }^{-/-}$mice treated with GnRH Vivo-Morpholino compared to $\mathrm{Mdr}^{-1-}$ treated with mismatch Vivo-Morpholino. Scale bars $=25 \mu \mathrm{m}(\mathbf{A})$. Original magnification, $\times 40$ (B). HNF- $4 \alpha$, hepatocyte nuclear factor- $4 \alpha$. 

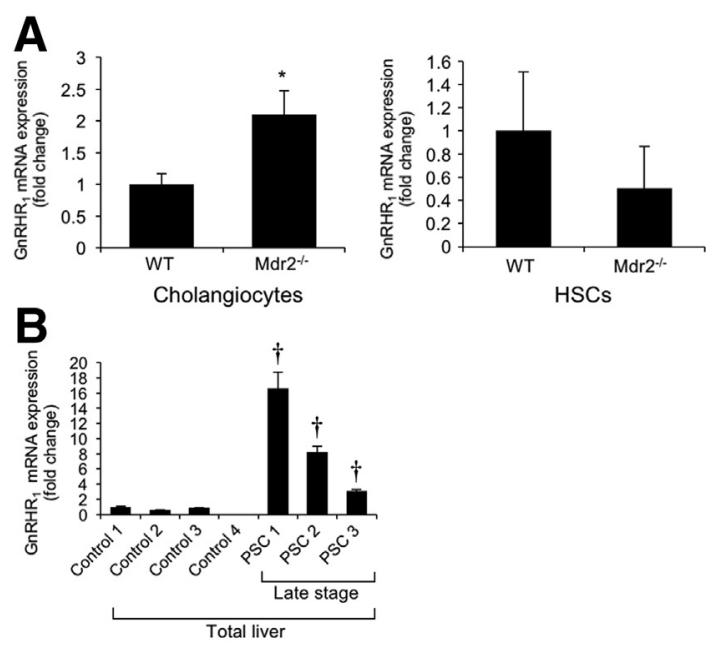

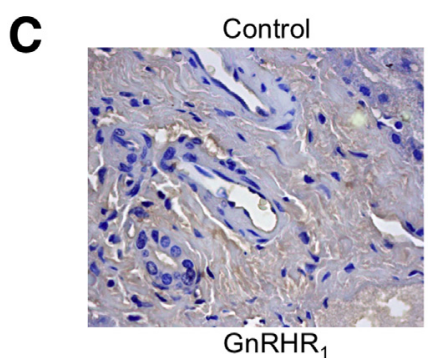

$(-)$

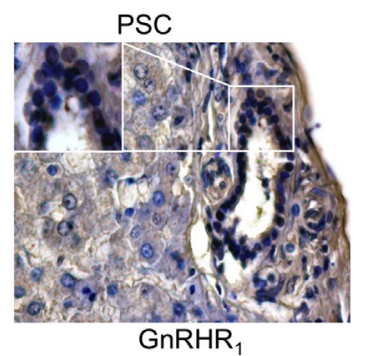

$(+)$
Figure 2 A and B: mRNA expression of $\mathrm{GnRHR}_{1}$ in isolated cholangiocytes is enhanced but not in LCM-isolated stellate cells from Mdr2 ${ }^{-1-}$ compared to WT mice $(\mathbf{A})$ and in total liver samples from late-stage human PSC samples compared to healthy controls (B). A: For isolated cholangiocytes, data are from eight PCRs from three cumulative preparations of cholangiocytes from four mice. For LMC-isolated HSCs, data are from seven real-time PCRs from one preparation of LCM-isolated HSCs from one mouse. B: Data are from three PCRs from three different samples from four normal healthy control and three PSC patients. C: There is immunoreactivity for $\mathrm{GnRHR}_{1}$ in bile ducts from PSC samples but not in control human samples. Data are expressed as means $\pm \operatorname{SEM}(\mathbf{A}$ and $\mathbf{B}) . n=12$ isolated cholangiocytes (A); $n=7$ LMC-isolated HSCs (A); $n=3$ PSC patients (B); $n=$ 4 normal healthy controls (B); $n=1$ control human samples (C); $n=1$ PSC patient (C). ${ }^{*} P<0.05$ versus WT mice; ${ }^{\dagger} P<0.05$ versus healthy human samples. Original magnification, $\times 40($ C) .

GnRH and mismatched Vivo-Morpholinos were obtained from Gene Tools, LLC (Philomath, OR). The GnRHR antagonist, cetrorelix acetate (referred to as cetrorelix), ${ }^{14,25}$ was purchased from R\&D Systems (Minneapolis, MN). Control and miR-200b inhibitors were purchased from Ambion Inc. (Austin, TX).

\section{Animal Models}

FVB/NJ wild-type (WT) and Mdr2 ${ }^{-/-}$mice (25 to $30 \mathrm{~g}, 12$ weeks old) were purchased from Jackson Laboratories (Sacramento, CA), were housed in a temperature-controlled environment $\left(22^{\circ} \mathrm{C}\right)$, were fed standard mice chow, and had access to drinking water ad libitum. The studies were performed in WT mice treated with saline or GnRH (250 ng/ kg body weight $)^{26,27}$ by i.p. implanted Alzet osmotic minipumps for 1 week. In separate experiments, $\mathrm{Mdr} 2^{-/-}$ mice were treated with the following: Vivo-Morpholino sequences against GnRH (5'-GATCGTTTCCATTCTGTTTGGATGT-3', $1 \mathrm{mg} / \mathrm{kg}$ body weight/day to reduce the hepatic expression of $\mathrm{GnRH}$ ) or mismatch VivoMorpholino sequences (5'-GAACCTTTCGATTCTCTTTCGATGT-3') administrated by two tail vein injections for 1 week $^{14}$; or cetrorelix $(10 \mathrm{mg} / \mathrm{kg} \text { body weight/day })^{28}$ by i.p. implanted Alzet osmotic minipumps for 1 week. Before each experimental procedure, animals were treated with 200 to $250 \mathrm{mg} / \mathrm{kg}$ body weight euthasol following the regulations of the panel on euthanasia of the American Veterinary Medical Association. All animal experiments were performed in accordance with protocols approved by the Baylor Scott \& White Health Institutional Animal Care and Use Committee.

\section{Isolated Cholangiocytes and HSCs, IMCLs, and HHSteCs}

Cholangiocytes were isolated by immunoaffinity separation $^{5,6}$ using a monoclonal antibody (IgM; a gift from Dr. Ronald A. Faris, Brown University, Providence, RI). Cell number and viability were assessed by trypan blue exclusion. HSCs from mouse liver were isolated by laser capture microdissection (LCM) as follows: briefly, frozen liver sections ( $n=3,10 \mu \mathrm{m}$ thick) were incubated overnight with a desmin (marker of HSCs) ${ }^{29}$ antibody. After washes, sections were incubated with a fluorescent secondary antibody. Next, desmin-positive cells were captured from slides by the LCM system Leica LMD7 (Leica Microsystems, Buffalo Grove, IL) and collected. RNA was extracted with the Arcturus PicroPure RNA isolation kit (Thermo Fischer Scientific, Mountain View, CA). The in vitro studies were performed in immortalized murine cholangiocyte lines (IMCLs), which display morphological, phenotypic, and functional characteristics similar to those of freshly isolated mouse cholangiocytes, ${ }^{5,6,30}$ and in HHSteCs that were purchased from Sciencell (Carlsbad, CA).

\section{Expression of $\mathrm{GnRHR}_{1}$ in Liver Sections, Cholangiocytes, and LCM-Isolated HSCs}

The expression of GnRHR 1 (the only GnRH receptor subtype that mediates $\mathrm{GnRH}$ effects on cholangiocytes) ${ }^{14}$ was evaluated by the following: immunofluorescence in frozen liver sections (4 to $5 \mu \mathrm{m}$ thick) costained with CK-19 (a cholangiocyte-specific marker), ${ }^{31}$ synaptophysin (a marker of HSCs), ${ }^{4}$ or hepatocyte nuclear factor- $4 \alpha$ (a hepatocyte marker) ${ }^{32}$; and semiquantitative immunohistochemistry in paraffin-embedded liver sections ( 4 to $5 \mu \mathrm{m}$ thick, 10 different fields analyzed from three samples from three different animals). We evaluated the expression of $\mathrm{GnRHR}_{1}$ by real-time PCR in total RNA $(1 \mu \mathrm{g})$ from isolated cholangiocytes and LCM-isolated HSCs. After immunohistochemistry, sections were then observed with Leica Microsystems DM 4500 B Microscopy (Weltzlar, Germany) equipped with a Jenoptik Prog Res C10 Plus Videocam (Jena, Germany). Observations 
were processed with an Image Analysis System (Delta Sistemi, Rome, Italy). After immunofluorescence, sections were stained with DAPI (ThermoFisher Scientific) and analyzed by an Olympus Fluoview 300 confocal microscope (Olympus, Center Valley, PA).

Measurement of GnRH Expression in Liver Sections, Cholangiocytes, LCM-Isolated HSCs, and GnRH Levels in Cholangiocyte Supernatant and Human Serum Samples

We measured the expression of $\mathrm{GnRH}$ by the following: i) immunofluorescence in frozen liver sections (4 to $5 \mu \mathrm{m}$ thick) costained with CK-19, hepatocyte nuclear factor- $4 \alpha$, or synaptophysin; ii) semiquantitative immunohistochemistry in paraffin-embedded liver sections (4 to $5 \mu \mathrm{m}$ thick, 10 different fields analyzed from three samples from three different animals); and iii) real-time PCR in total RNA (1 $\mu \mathrm{g})$ from isolated cholangiocytes and LCM-isolated HSCs. To demonstrate the specificity of the immunoreactions, negative controls (the primary antibody was replaced with the same dilution with normal serum from the same species) were performed for all immunoreactions. Sections were analyzed in a coded manner using Leica Microsystems DM 4500 B Microscopy equipped with a Jenoptik Prog Res C10 Plus Videocam (Jena, Germany). Observations were processed with an Image Analysis System (Delta Sistemi). We measured the levels of GnRH in the supernatant of purified cholangiocytes
A
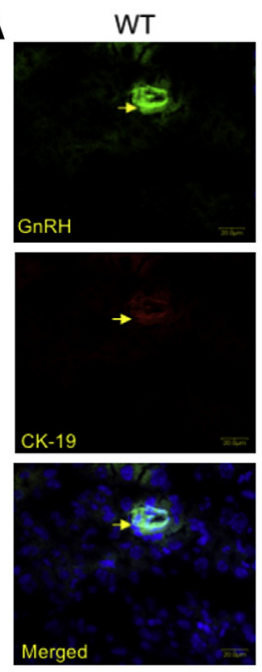

Cholangiocytes
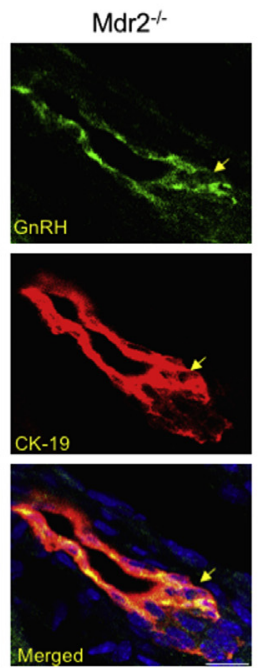
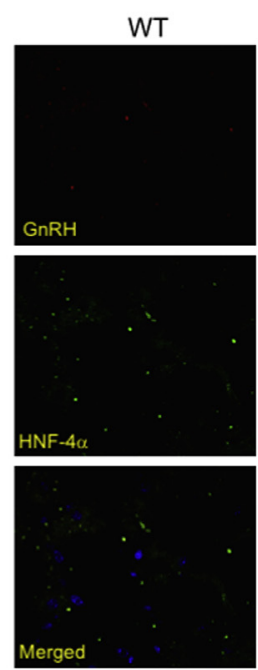

Hepatocytes
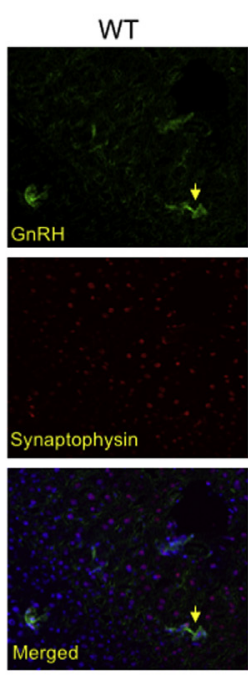

HSCs

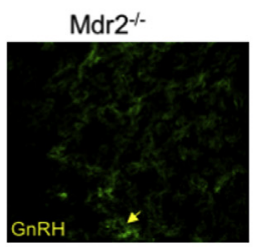

B

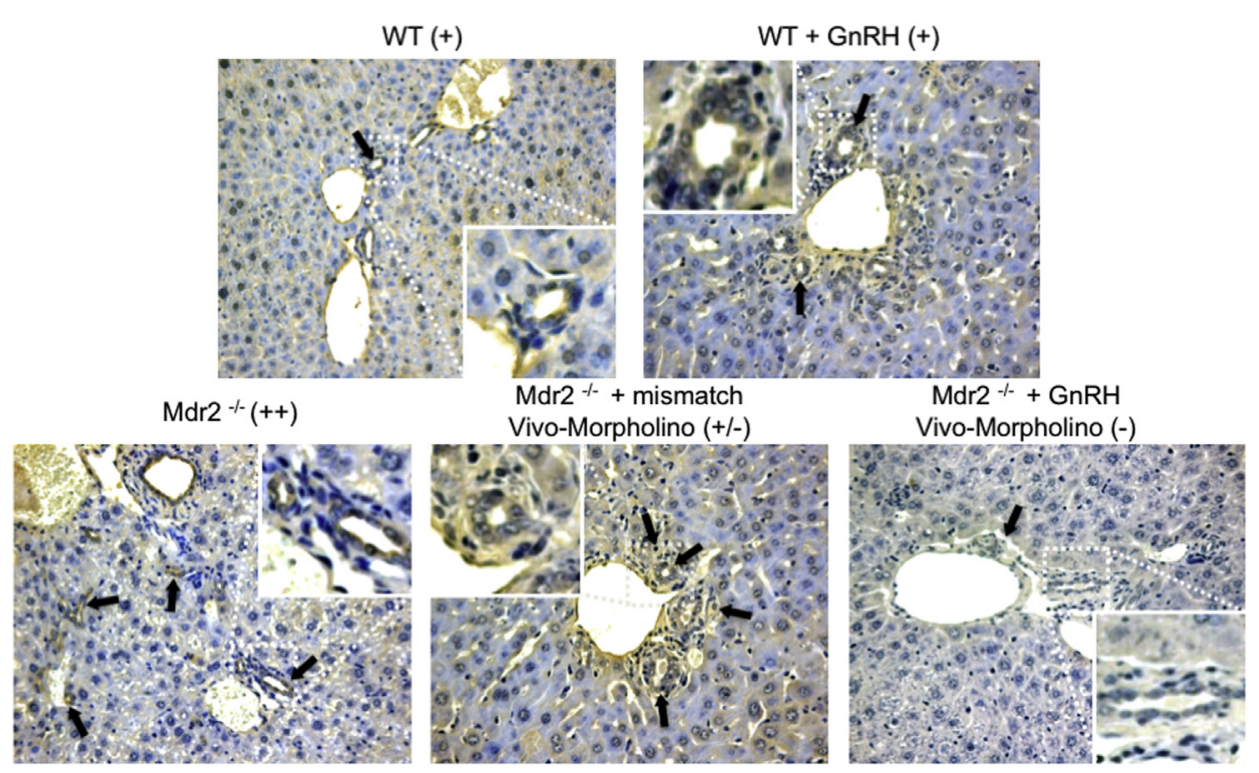

Figure 3 A: Bile ducts and HSCs (but not hepatocytes) display immunoreactivity for GnRH. Nuclei were stained with DAPI (blue). Localization of GnRH and CK-19 in bile ducts is indicated by yellow arrows. B: By immunohistochemistry, the immunoreactivity of GnRH (black arrows) increases in Mdr2 ${ }^{-/-}$mice compared to WT mice; and decreases in Mdr2 ${ }^{-/-}$mice treated with GnRH Vivo-Morpholino compared to Mdr2 ${ }^{-/-}$mice and Mdr2 ${ }^{-/-}$mice treated with mismatch Vivo-Morpholino. Scale bars $=25 \mu \mathrm{m}$ (A). Original magnification, $\times 20$ (B). HNF-4 $\alpha$, hepatocyte nuclear factor- $4 \alpha$. 

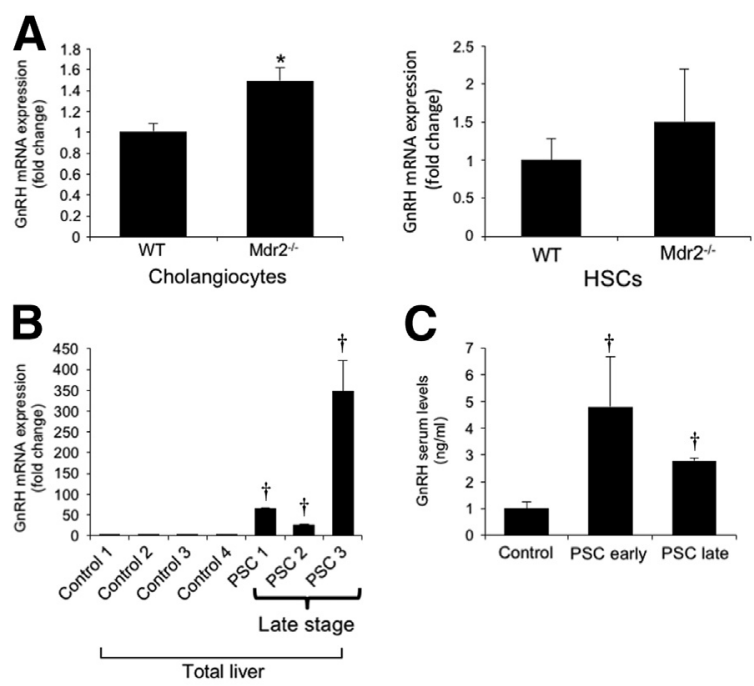

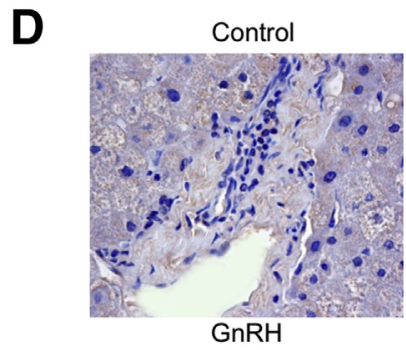

$(-)$

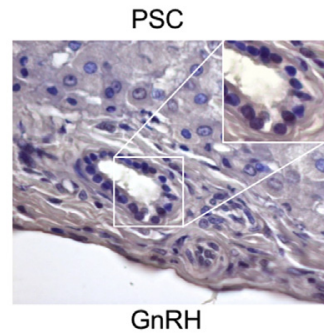

$(+)$
Figure $4 \quad$ A and $\mathbf{B}$ : There is enhanced mRNA expression of $\mathrm{GnRH}$ in isolated cholangiocytes but not LMC-isolated stellate cells from $\mathrm{Mdr}^{-/}$ compared to WT mice (A) and increased expression of GnRH in total liver from late-stage human PSC compared to healthy control samples (B). A: For isolated cholangiocytes, data are from eight PCRs from three cumulative preparations of cholangiocytes from four mice. For LMC-isolated HSCS, data are from seven real-time PCRs from one preparation of LCM-isolated HSCs from one mouse. B: Data are from three PCRs from three different samples from four healthy controls and three late-stage PSC patients. C: There are enhanced $\mathrm{GnRH}$ levels in the serum of early- and late-stage human PSC patients compared to healthy controls. D: By immunohistochemistry, there is immunoreactivity for GnRH in cholangiocytes from late-stage PSC sample (a lower and higher magnification are shown) but not in human control liver sample; there is no immunoreactivity for GnRH in hepatocytes from control and PSC liver sections. Data are expressed as means $\pm \operatorname{SEM}(\mathbf{A}$ and $\mathbf{B}) \cdot n=12$ isolated cholangiocytes (A); $n=7$ LMC-isolated HSCs (A); $n=8$ early-stage PSC (C); $n=4$ late-stage PSC (C); $n=7$ healthy controls $(\mathbf{C}) ; n=1$ control human samples (D); $n=1$ PSC patient (D). ${ }^{*} P<0.05$ versus WT mice; ${ }^{\dagger} P<0.05$ versus control human samples. Original magnification, $\times 40$ (D).

as well as serum from the selected human samples using commercially available enzyme-linked immunosorbent assay assay kits following the manufacturer's instructions (IBLAmerica, Minneapolis, MN).

\section{Measurement of IBDM and Liver Fibrosis}

Intrahepatic bile duct mass (IBDM) in liver sections (4 to 5 $\mu \mathrm{m}$ thick, 10 different fields analyzed from three samples from three different animals) was measured by semiquantitative immunohistochemistry as the area occupied by CK-19-positive bile ducts/total area $\times 100^{5}$. Sections were examined using the Olympus Image Pro-Analyzer software version 7.0 (Olympus, Tokyo, Japan). We also evaluated by real-time PCR the mRNA expression of PCNA and Ki-67 in total liver and isolated cholangiocytes from WT and $\mathrm{Mdr} 2^{-1-}$ mice and Mdr2 ${ }^{-1-}$ mice treated with cetrorelix.

Hepatic fibrosis was evaluated by Sirius Red staining in paraffin-embedded liver sections (4 to $5 \mu \mathrm{m}$ thick, 10 different fields analyzed from three samples from three different animals). Slides were scanned by a digital scanner (SCN400; Leica Microsystems, Buffalo Grove, IL) and quantified using Image-Pro Premier 9.1 (Media Cybernetics, Rockville, MD). We evaluated in isolated cholangiocytes the mRNA expression of the fibrosis genes, TGFB1, $T G F B 1 R$, and Serpine1, by real-time PCR.

\section{Expression of miR-200b in Total Liver and Cholangiocytes}

To demonstrate that the effects of GnRH on biliary proliferation and liver fibrosis are mediated by changes in biliary miR-200b expression, we evaluated by real-time PCR the expression of miR-200b in total liver and isolated cholangiocytes from WT mice treated with saline or $\mathrm{GnRH}$ as well as $\mathrm{Mdr} 2^{-1-}$ mice. The rationale for evaluating the role of $\mathrm{miR}-200 \mathrm{~b}$ in these models is based on findings showing that the expression of miR-200b markedly increased in $\mathrm{Mdr} 2^{-/-}$mice compared to WT mice as well as human PSC samples compared to healthy controls (N. Wu and G. Alpini, unpublished data).

\section{Effect of GnRH on the Expression of miR-200b and Fibrosis Genes in Vitro}

The in vitro experiments were performed in IMCLs and HHSteCs that were stimulated with $0.2 \%$ bovine serum albumin (basal) or $\mathrm{GnRH}(100 \mathrm{nmol} / \mathrm{L})^{14}$ for 48 hours at $37^{\circ} \mathrm{C}$ in the absence or presence of $10 \mathrm{nmol} / \mathrm{L}$ cetrorelix; after stimulation, we measured the expression of miR-200b and/ or PCNA, Ki-67, and the fibrosis genes, TGFB1, TGFB1R, and Serpine1, by real time-time PCR in IMCLs, and TGFB1, TGFB1R, MMP9, and Serpine1 in HHSteCs.

Table 3 Measurement of GnRH Levels in Cholangiocyte Supernatant

\begin{tabular}{lrrr}
\hline Treatment & Normal WT mice & Normal WT mice + GnRH & Mdr2 ${ }^{-/-}$mice \\
\hline Body weight, g & $25.3 \pm 0.8(23)$ & $28.1 \pm 0.4(10)$ & $26.4 \pm 0.4(29)$ \\
Cholangiocyte GnRH supernatant, $\mathrm{ng} / \mathrm{mL}$ & $0.5 \pm 0.2(20)$ & $7.95 \pm 1.0(13)^{*}$ & $11.46 \pm 5.4(21)^{*}$ \\
\hline
\end{tabular}

Data are expressed as means $\pm \operatorname{SEM}(n)$.

${ }^{*} P<0.05$ versus normal WT mice.

$\mathrm{GnRH}$, gonadotropin-releasing hormone; $\mathrm{Mdr}^{-/-}$, multidrug resistance gene 2 knockout; WT, wild type. 
A
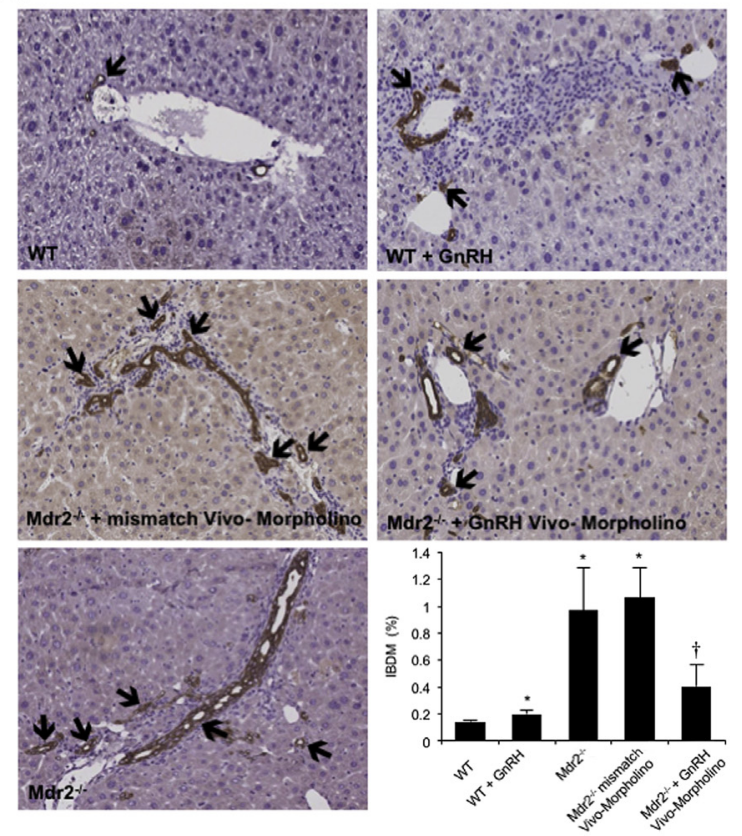

B
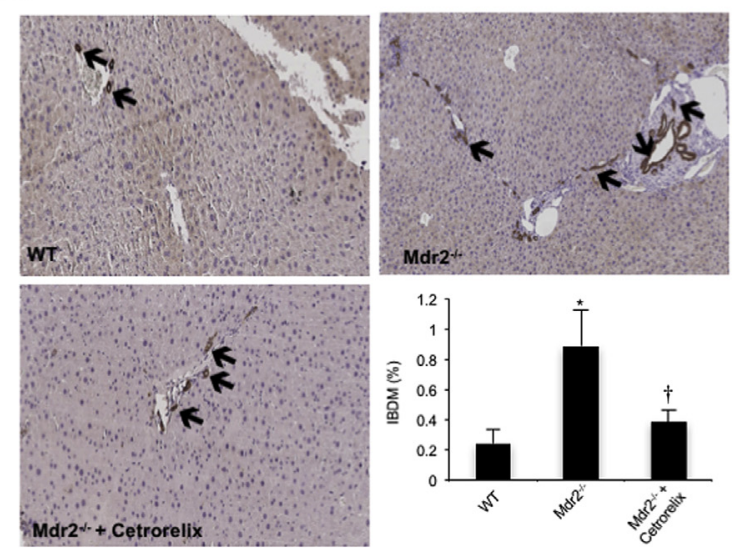

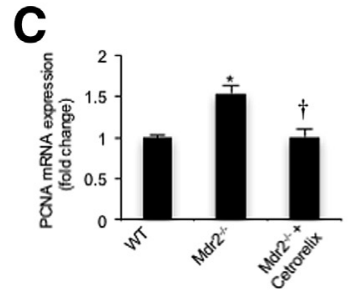

Total Liver

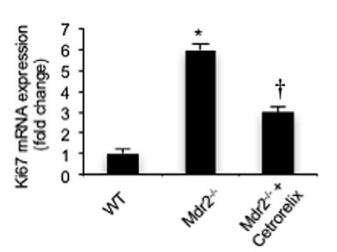

Total Liver
D
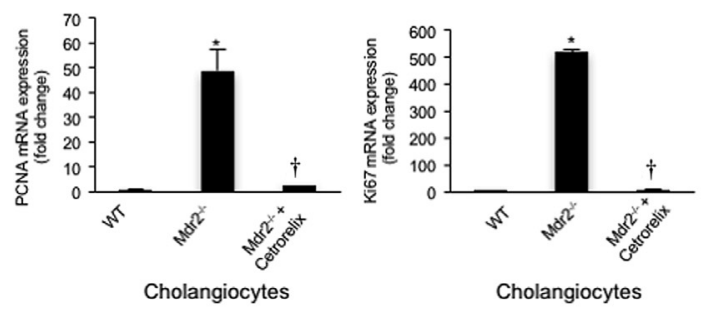

We evaluated the expression of GnRH in IMCLs and GnRHR $_{1}$ in IMCL and HHSteC smears by immunofluorescence. In separate experiments, control (stable transfected with the empty vector) or GnRH stable-transfected IMCLs were cultured until confluency before evaluating the following: GnRH levels in cholangiocyte supernatant (after incubation for 4 hours at $\left.37^{\circ} \mathrm{C}\right)^{6}$ by enzyme immunoassay kits; and the expression of miR-200b and selected fibrosis genes by real-time PCR. In separate experiments, HHSteCs were incubated for 12 hours with the supernatant of Neg- or shGnRH-transfected IMCLs (containing different levels of $\mathrm{GnRH}$ ) before evaluating the expression of miR-200b and selected fibrosis gene factors by real-time PCR in these cells. Control IMCLs (stable transfected with the empty vector) or IMCLs lacking GnRH were established using SureSilencing shRNA (Super-Array, Frederick, MD) plasmid for mouse $\mathrm{GnRH}$ containing a marker for neomycin resistance for the selection of stably transfected cells, according to the instructions provided by the vendor. ${ }^{14} \mathrm{We}$ have previously used this approach to establish IMCLs lacking the gene for secretin and its receptor. ${ }^{5,6}$

To demonstrate a link between GnRH, miR-200b, and liver fibrosis, IMCLs and HHSteCs were treated with miR$200 \mathrm{~b} /$ control precursor and/or antisense inhibitors and controls (Ambion, Austin, TX) in the absence or presence of 100 $\mathrm{nmol} / \mathrm{L} \mathrm{GnRH}$ for 24 hours before evaluating the expression of selected fibrosis genes by real-time PCR assay.

Measurement of $\mathrm{GnRH}$ and $\mathrm{GnRHR}_{1}$ Immunoreactivity and Expression of GnRH and GnRH Serum Levels in Normal and PSC Patients

Unidentified human samples collected by needle biopsies (Tables 1 and 2) were obtained from Dr. Pietro Invernizzi (Humanitas Research Hospital, Rozzano, Italy) under a protocol approved by the Ethics Committee by the Humanitas Research Hospital and also reviewed by the Central Texas Veteran's Health Care System Institutional Review Board and Research \& Development Committee. The protocol was also approved by the Texas A\&M HSC College of Medicine Institutional Review Board.

We evaluated the immunoreactivity of $\mathrm{GnRHR}_{1}$ and $\mathrm{GnRH}$ in one liver section from a healthy male and a late-stage male

\footnotetext{
Figure 5 There is enhanced intrahepatic biliary mass (IBDM) in WT mice treated with GnRH compared to WT mice. A and B: IBDM increases in Mdr2 ${ }^{-/-}$ mice as well as mismatched-treated $\mathrm{Mdr}^{-1-}$ mice compared to WT mice, and returns to values similar to that of WT mice in $M \mathrm{dr}^{-1-}$ mice treated with GnRH Vivo-Morpholino (A) or cetrorelix (B). Data are from 10 cumulative values obtained from three slides from each group. Arrows indicate CK-19-positive bile ducts. C and D: Cetrorelix reduces the mRNA expression of PCNA and Ki-67 in total liver (C) and isolated cholangiocytes (D) from $\mathrm{Mdr}^{-1-}$ mice. Data are from three real-time PCRs from three different total liver samples $(\mathbf{C})$ and four real-time PCRs from three cumulative preparations of cholangiocytes from four mice (D). Data are expressed as means \pm SEM. $n=12$ (C and D). ${ }^{*} P<0.05$ versus WT mice; ${ }^{\dagger} P<0.05$ versus $\mathrm{Mdr}^{-/-}$mice. Original magnification, $\times 20$ (A and $\mathbf{B})$.
} 

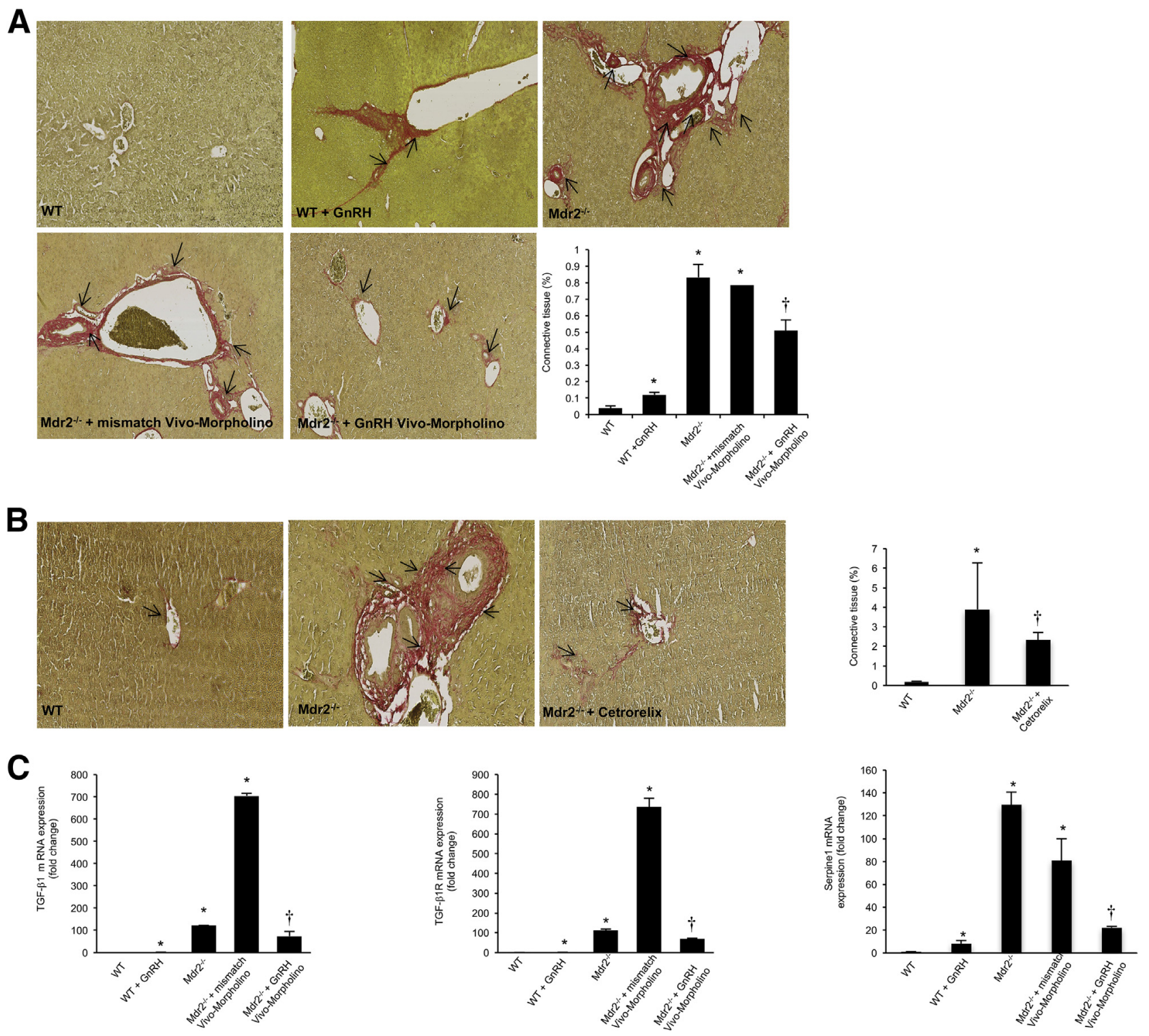

\section{Cholangiocytes}
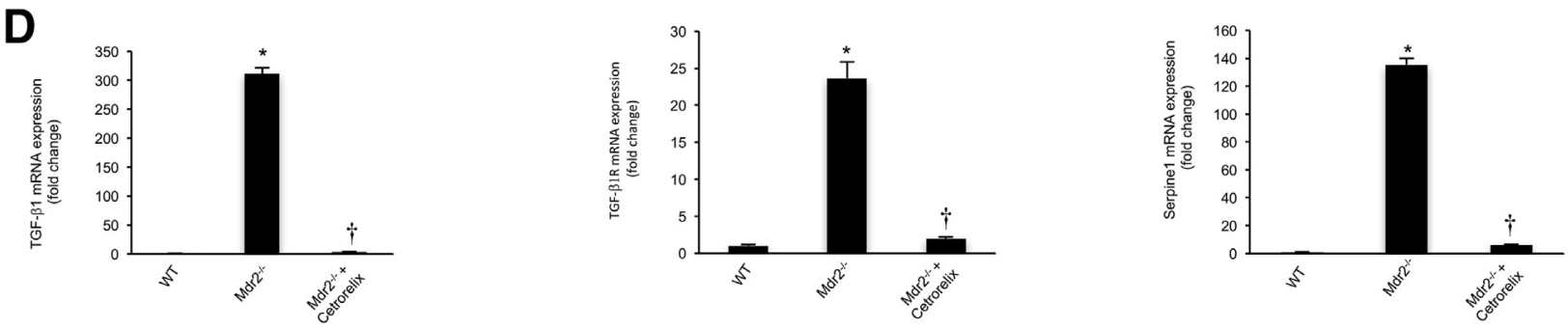

\section{Cholangiocytes}

Figure 6 A-C: Liver fibrosis and fibrosis gene expression increases in isolated cholangiocytes from WT mice treated with GnRH compared to WT mice. $\mathbf{B}$ and D: The increase in liver fibrosis and fibrosis gene expression (observed in Mdr2 ${ }^{-/-}$mice as well as Mdr2 ${ }^{-/-}$mice treated with mismatch Vivo-Morpholino) is reduced by the administration of GnRH Vivo-Morpholino or cetrorelix, respectively. A and B: Data are from 10 cumulative values obtained from three different slides from three different mice. Arrows indicate the collagen deposition around bile ducts. C: Data are from four real-time PCRs from three cumulative preparations of cholangiocytes from four mice. Values are as follows: WT, $1.0 \pm 0.08$, and WT + GnRH, $1.8 \pm 0.1$ for TGF- $\beta 1$; WT, $1.0 \pm 0.04$, and $\mathrm{WT}+\mathrm{GnRH}, 1.5 \pm 0.2$ for TGF- $\beta 1 \mathrm{R}$. Data are expressed as means \pm SEM (A-D). $n=12$ (C). ${ }^{*} P<0.05$ versus WT mice; ${ }^{\dagger} P<0.05$ versus Mdr2 ${ }^{-/-}$mice. Original magnification, $\times 40(\mathbf{A}$ and $\mathbf{B})$. 

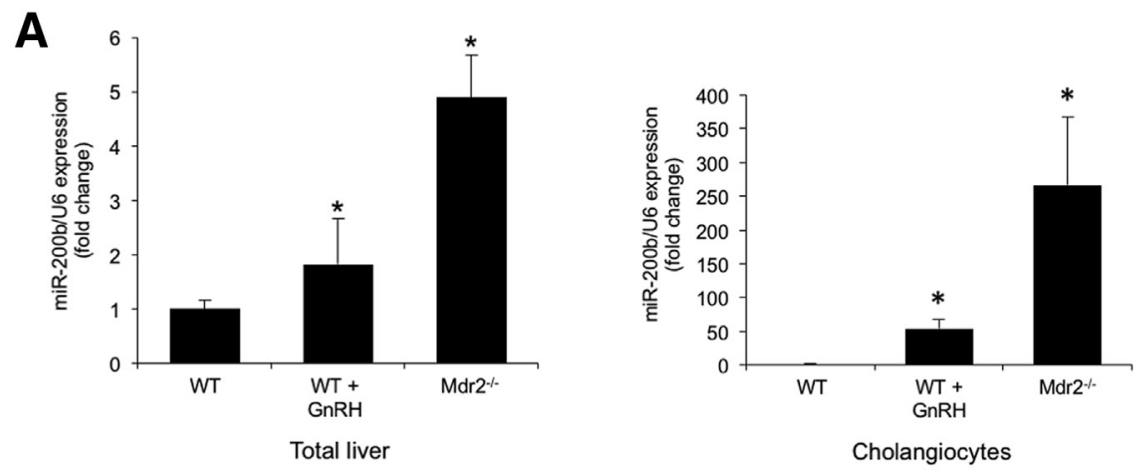

B
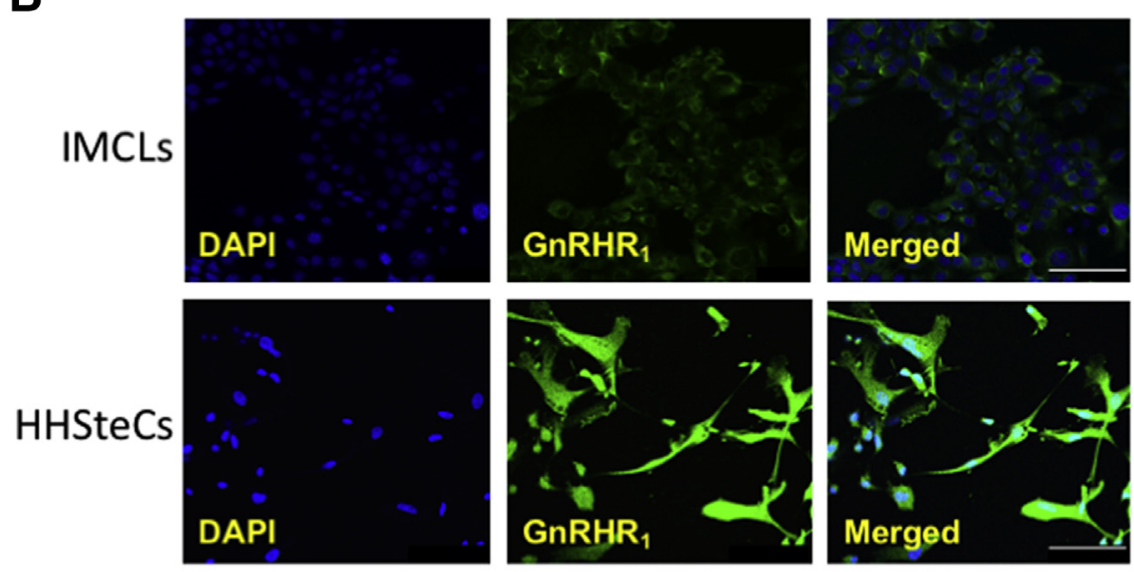

Figure 7 A: The expression of miR-200b increases in total liver and isolated cholangiocytes from normal WT mice treated with GnRH compared to WT mice as well as $\mathrm{Mdr2}^{-/-}$mice compared to WT mice. Data are from 16 real-time PCRs from three cumulative preparations of cholangiocytes from four mice. GnRH increases the expression of miR-200b in IMCLs and HHSteCs (C) that are immunoreactive for $\mathrm{GnRHR}_{1}$ (B). Nuclei were stained with DAPI (blue). C: Data are from four realtime PCRs from four individual preparations of IMCLS and HHSteCs. Data are expressed as means \pm SEM. $n=12(\mathbf{A}) ; n=4$ (C). ${ }^{*} P<0.05$ versus WT mice; ${ }^{\dagger} P<0.05$ versus basal. Scale bars $=25 \mu \mathrm{m}$ (B).

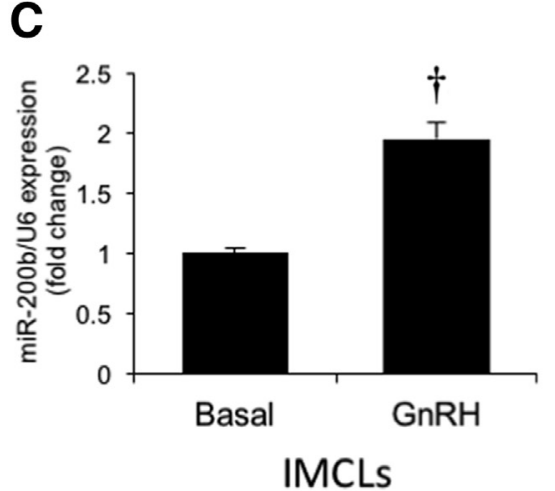

PSC patient by immunohistochemistry. After staining, sections were then observed with Leica Microsystems DM 4500 B Microscopy equipped with a Jenoptik Prog Res C10 Plus Videocam. Observations were processed with an Image Analysis System (Delta Sistemi). For real-time PCR analysis, total RNA was extracted from paraffin-embedded sections from samples obtained from four normal control and three late-stage PSC patients using the RNeasy FFPE kit (73504; Qiagen, Valencia, CA). From these samples, the mRNA expression (from cDNA samples) for human GnRHR $_{1}$ (NM_001012763), GnRH (NM_000825), and glyceraldehyde-3-phosphate dehydrogenase (NM_002046) was evaluated by real-time PCR using human primers purchased from Qiagen. GnRH serum levels in control $(n=7)$, early-stage $(n=8)$, and late-stage $(n=4)$ male PSC samples were evaluated by enzyme immunoassay.

\section{Statistical Analysis}

All data are expressed as means \pm SEM. Differences between groups were analyzed by unpaired $t$-test when two groups were analyzed and analysis of variance when more than two groups were analyzed, followed by an appropriate post hoc test.

\section{Results}

\section{Expression of $\mathrm{GnRHR}_{1}$}

By immunofluorescence in liver sections from WT and $\mathrm{Mdr} 2^{-1-}$ mice, we demonstrated immunoreactivity for GnRHR $_{1}$ in intrahepatic bile ducts and HSCs (costained with CK-19 and synaptophysin, respectively) (Figure 1A); 


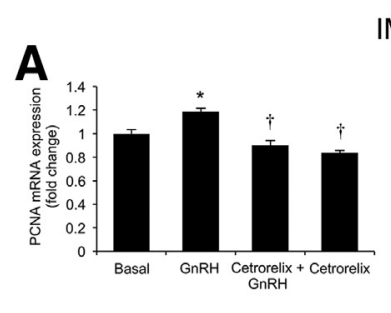

IMCLs
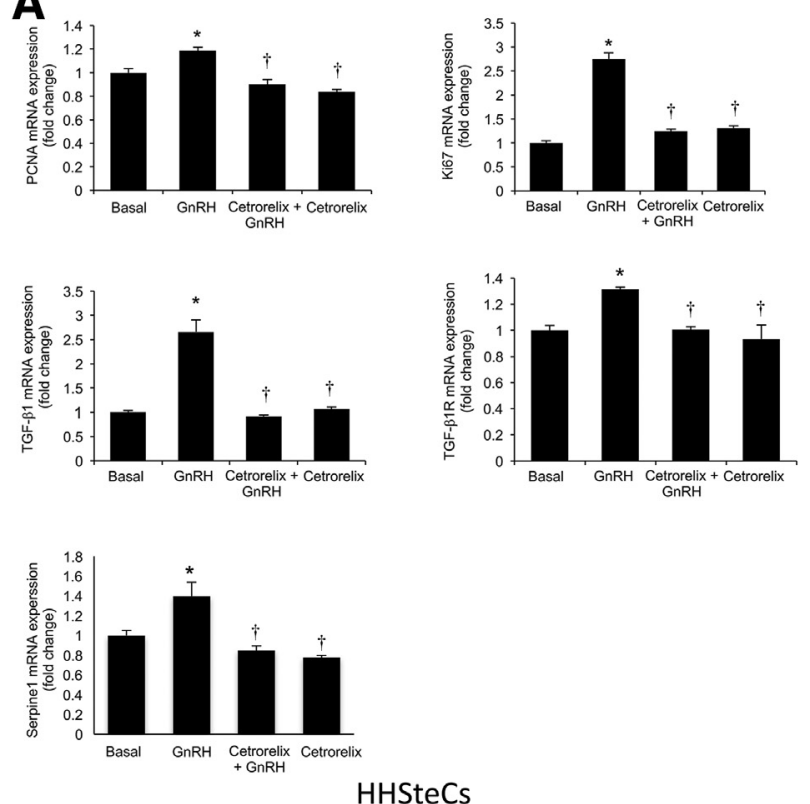

HHSteCs

B
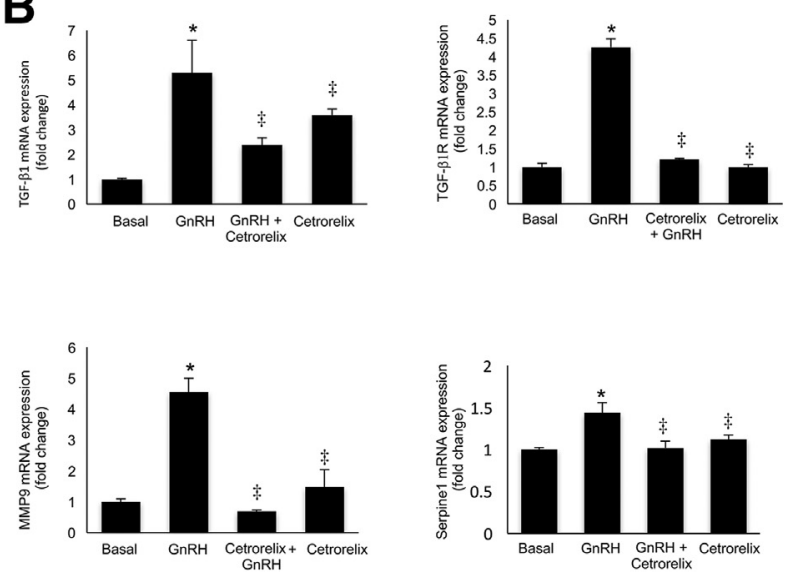

Figure 8 A: In vitro, GnRH increases the expression of miR-200b, proliferation, and selected fibrosis genes in IMCLs, which is reduced by preincubation with cetrorelix. Data are from four real-time PCRs from four individual preparations of IMCLs. B: GnRH increases the expression of selected fibrosis genes in HHSteCs compared to basal that is reduced by preincubation with cetrorelix. Data are from four PCRs from four individual preparations of HHSteCs. Data are expressed as means \pm SEM. ${ }^{*} P<0.05$ versus basal; ${ }^{\dagger} P<0.05$ versus IMCLs treated with GnRH; and ${ }^{\ddagger} P<0.05$ versus HHSteCs treated with $\mathrm{GnRH}$.

the immunoreactivity of $\mathrm{GnRHR}_{1}$ was virtually absent in hepatocytes costained with hepatocyte nuclear factor- $4 \alpha$ (Figure 1A). By semiquantitative immunohistochemistry in liver sections, we demonstrated the following: cholangiocytes express $\mathrm{GnRHR}_{1}$; and there was enhanced immunoreactivity for $\mathrm{GnRHR}_{1}$ in cholangiocytes from WT mice treated with $\mathrm{GnRH}$ and $\mathrm{Mdr} 2^{-1-}$ mice and $M d r 2^{-1-}$ mice treated with mismatch Vivo-Morpholino compared to the corresponding control mice (Figure 1B). The expression of $\mathrm{GnRHR}_{1}$ decreased in cholangiocytes from $\mathrm{Mdr}^{-1-}$ mice treated with $\mathrm{GnRH}$
Vivo-Morpholino compared to Mdr2 $2^{-1-}$ mice treated with mismatch Vivo-Morpholino (Figure 1B). There was enhanced mRNA expression of $\mathrm{GnRHR}_{1}$ in cholangiocytes (but not LCM-isolated HSCs) from Mdr2 $2^{-/-}$ mice compared to WT mice (Figure 2A) and increased mRNA expression of $\mathrm{GnRHR}_{1}$ in total liver samples from late-stage male PSC patients $(n=3)$ compared to their healthy controls $(n=4)$ (Figure 2B). By immunohistochemistry in a human liver section, we did not detect expression for $\mathrm{GnRHR}_{1}$ in normal bile ducts, but we demonstrated immunoreactivity for the receptor in bile ducts from a late-stage male PSC sample (a lower and higher magnification are shown); the immunoreactivity for $\mathrm{GnRHR}_{1}$ was absent in hepatocytes from the control and PSC human liver section (Figure 2C).

\section{Measurement of GnRH Expression}

We demonstrated that cholangiocytes and HSCs (but not hepatocytes) are immunoreactive for GnRH by immunofluorescence in liver sections (Figure 3A). By immunohistochemistry, we demonstrated that GnRH expression increased in liver sections from $\mathrm{Mdr}^{-/-}$compared to WT mice (Figure 3B) and decreased in $\mathrm{Mdr} 2^{-/-}$mice treated with GnRH Vivo-Morpholino compared to both $\mathrm{Mdr} 2^{-1-}$ mice and $\mathrm{Mdr} 2^{--}$mice treated with mismatch Vivo-Morpholino (Figure 3B). There was enhanced mRNA expression of $\mathrm{GnRH}$ in isolated cholangiocytes (but not LCM-isolated HSCs) from Mdr2 ${ }^{-l-}$ compared to WT mice (Figure 4A) and enhanced mRNA expression of GnRH in total liver from late-stage human PSC samples $(n=3)$ compared to healthy control samples $(n=4)$ (Figure 4B). We observed enhanced GnRH levels in the serum of early- and late-stage male PSC patients compared to healthy controls (Figure 4C). By immunohistochemistry, we did not detect expression for $\mathrm{GnRH}$ in bile ducts from a liver section from a healthy control patient, but we demonstrated immunoreactivity for $\mathrm{GnRH}$ in bile ducts from a late-stage male PSC sample; the immunoreactivity for $\mathrm{GnRH}$ was absent in hepatocytes from both the control and PSC human liver section (a lower and higher magnification are shown) (Figure 4D). The immunoreactivity of $\mathrm{GnRH}$ was absent in hepatocytes from control and PSC human liver sections (Figure 4D). There was an increase in $\mathrm{GnRH}$ levels in cholangiocyte supernatant from WT mice treated with $\mathrm{GnRH}$ as well as in $\mathrm{Mdr} 2^{-1-}$ mice compared to WT mice (Table 3).

\section{Measurement of IBDM and Liver Fibrosis}

There was enhanced IBDM and liver fibrosis in WT mice treated with GnRH compared to WT mice (Figure 5A and Figure 6A). Increased IBDM and liver fibrosis (observed in $\mathrm{Mdr} 2^{-1-}$ mice and $\mathrm{Mdr} 2^{-1-}$ mice treated with mismatch Vivo-Morpholino) were reduced by the administration of GnRH Vivo-Morpholino (Figure 5A and Figure 6A) or cetrorelix (Figure 5B and Figure 6B). Cetrorelix was well 
A
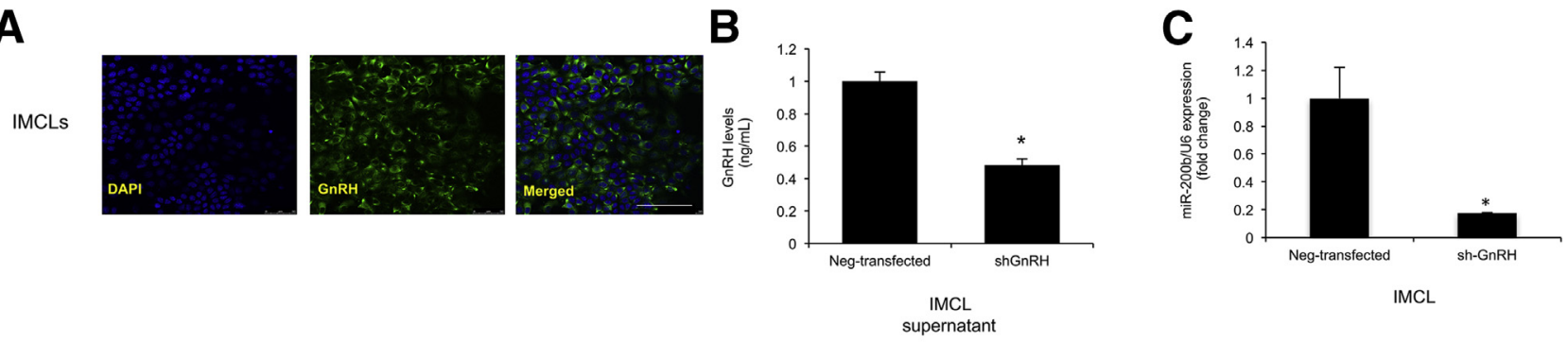

D
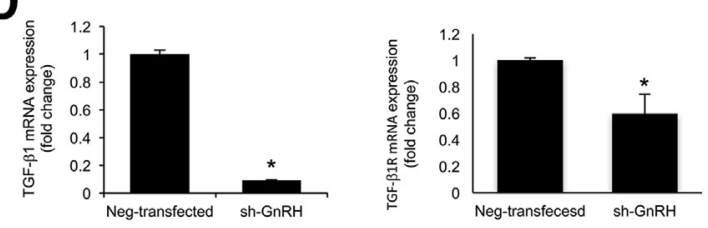

IMCLs
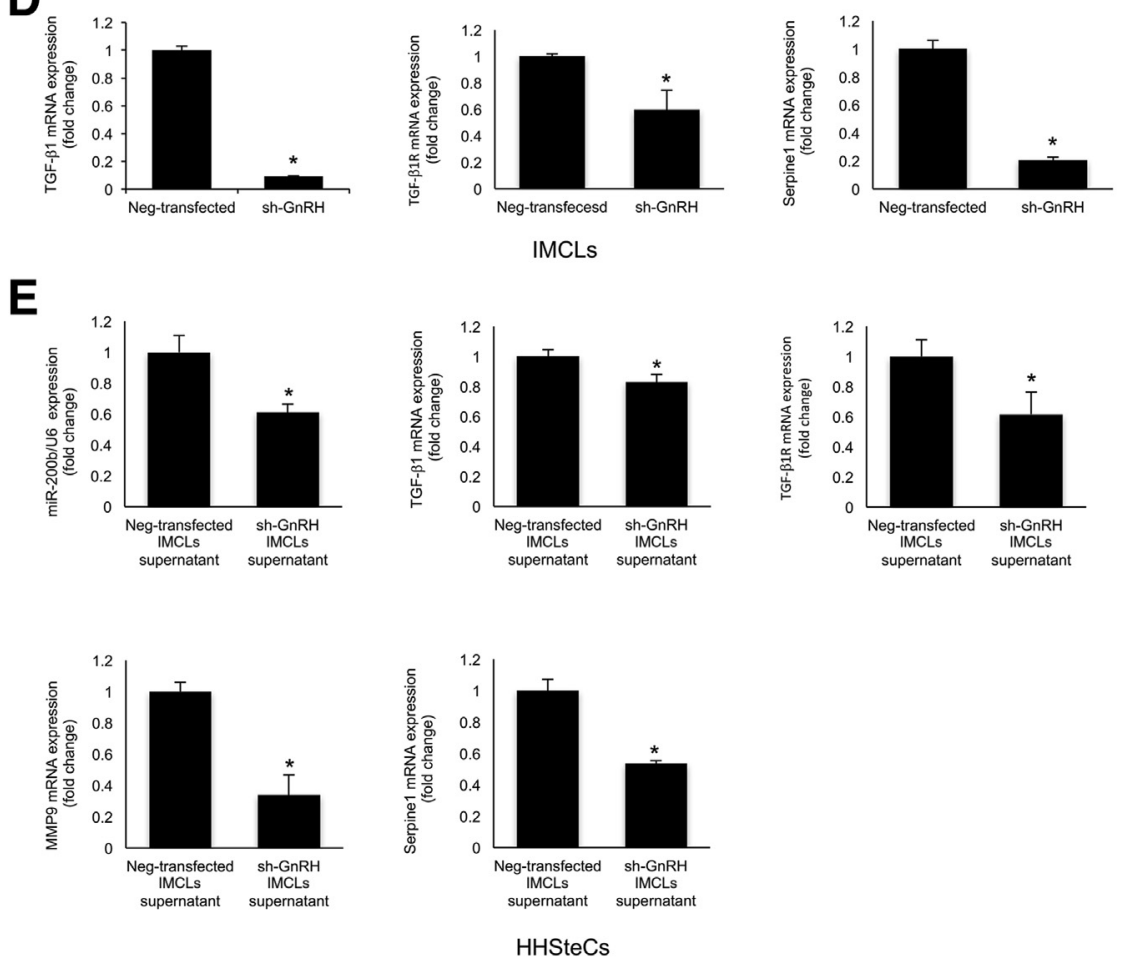

Figure 9 A: Immunofluorescence shows that IMCLs express immunoreactivity for GnRH. Nuclei were stained with DAPI (blue). B: In shGnRH IMCLs (expressing lower levels of GnRH), there is reduced expression of miR-200b (C) and selected fibrosis genes (D). C and D: Data are from three PCR real-time reactions from three different preparations of IMCL. E: When HHSteCs were incubated with the supernatant of shGnRH IMCLs, there was a decrease in the expression of miR$200 \mathrm{~b}$ and selected fibrosis genes compared to HHSteCs treated with the supernatant of Negtransfected IMCLs. Data are from four real-time PCRs from three different preparations of HHSteCs. Data are expressed as means \pm SEM. $n=4$ (B); $n=3$ (C and $\mathbf{D})$. ${ }^{*} P<0.05$ versus Neg-transfected IMCLs. Scale bar $=25 \mu \mathrm{m}(\mathbf{A})$. tolerated by the mice, with no changes in body weight and liver morphology (data not shown); in support of our finding, another study has shown that cetrorelix induces only mild damage to the liver. ${ }^{33}$ Cetrorelix reduces the mRNA expression of PCNA and Ki-67 (markers of proliferation) in total liver from $\mathrm{Mdr} 2^{-/-}$mice (Figure $5 \mathrm{C}$ ) as well as isolated cholangiocytes from $\mathrm{Mdr}^{-/-}$mice (Figure 5D). By real-time PCR, there was increased mRNA expression of TGF- $\beta 1$, TGF- $\beta 1 \mathrm{R}$, and Serpine 1 in isolated cholangiocytes from WT mice treated with GnRH compared to WT mice (Figure 6C). The increase in fibrosis gene expression (observed in $\mathrm{Mdr} 2^{-/-}$mice and $\mathrm{Mdr} 2^{-1-}$ mice treated with mismatch Vivo-Morpholino) was reduced by treatment with GnRH Vivo-Morpholino and cetrorelix (Figure 6, C and D).

\section{Modulation of the Expression of miR-200b and Fibrosis by the $\mathrm{GnRH} / \mathrm{GnRHR}_{1}$ Axis}

There was enhanced expression of miR-200b in total liver and isolated cholangiocytes from WT mice treated with
GnRH as well as Mdr2 $2^{-/-}$mice compared to the corresponding control mice (Figure 7A). By immunofluorescence, we demonstrated that IMCLs and HHSteCs express GnRHR $_{1}$ (Figure 7B). We also demonstrated that GnRH increased the expression of miR-200b in IMCLs and HHSteCs (Figure 7C). We also observed an increase in the mRNA expression of PCNA and Ki-67 (markers of cell proliferation), TGF- $\beta 1$, TGF- $\beta 1 \mathrm{R}$, and Serpine1 in IMCLs treated in vitro with GnRH, which was reduced by preincubation with cetrorelix (Figure 8A). Similarly, there was an increase in the expression of TGF- $\beta 1$, TGF- $\beta 1 \mathrm{R}$, matrix metalloproteinase 9, and Serpine1 in HHSteCs treated in vitro with $\mathrm{GnRH}$; this increase was reduced after preincubation with cetrorelix (Figure 8B).

By immunofluorescence, we demonstrated that IMCLs express immunoreactivity for GnRH (Figure 9A). In shGnRH IMCLs (expressing lower levels of GnRH) (Figure 9B) there was reduced expression of miR-200b (Figure 9C) and TGF- $\beta 1$, TGF- $\beta 1 \mathrm{R}$, and Serpine1 (Figure 9D). When HHSteCs were incubated with the supernatant of shGnRH IMCLs, there was a decrease in the 

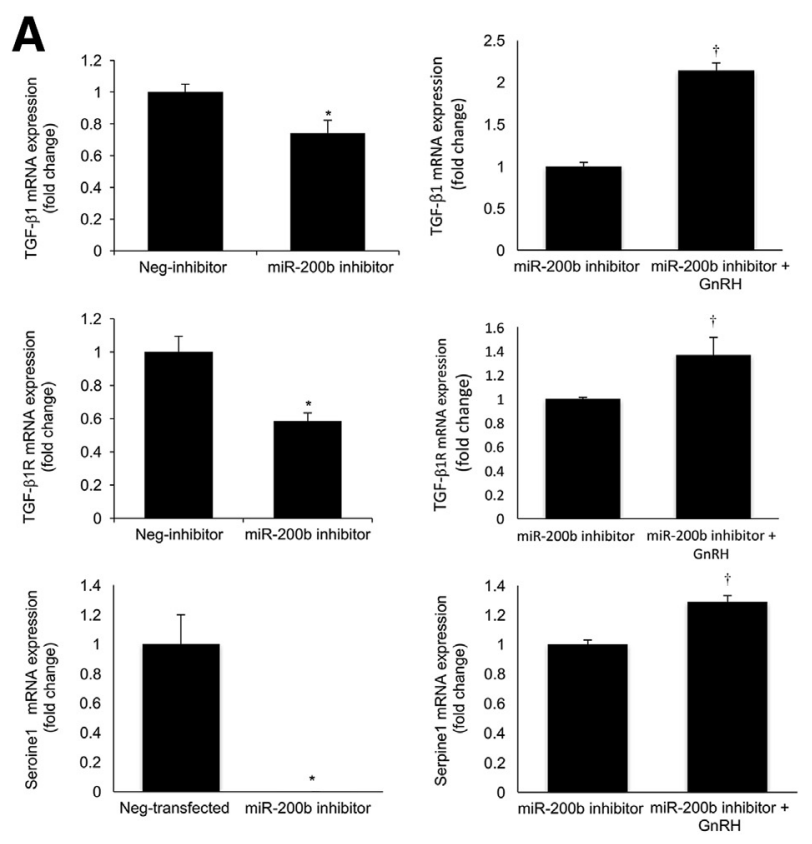

IMCLS
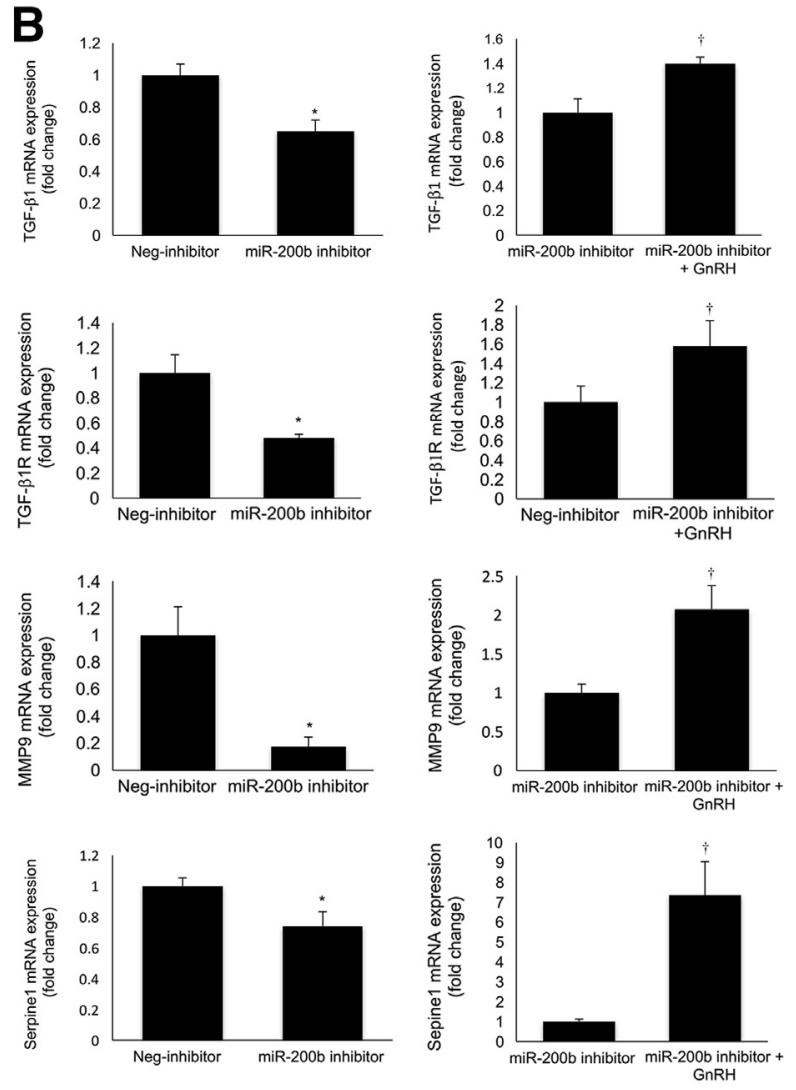

HHSteCs

Figure 10 A and B: In both IMCLs and HHSteCs treated with an miR$200 \mathrm{~b}$ antisense inhibitor, there is a reduced expression of selected fibrosis genes; the simultaneous treatment of IMCLs and HHSteCs with an miR-200b antisense inhibitor plus GnRH results in increased expression of fibrosis genes. Data are expressed as means \pm SEM of four real-time PCRs from three different preparations of IMCLs (A) and HHSteCs (B). ${ }^{*} P<0.05$ versus $\mathrm{Neg}$-inhibitor; ${ }^{\dagger} P<0.05$ versus miR-200b inhibitor. expression of miR-200b and TGF- $\beta 1$, TGF- $\beta 1 \mathrm{R}$, matrix metalloproteinase 9, and Serpine1 compared to HHSteCs treated with the supernatant of Neg-transfected IMCLs (Figure 9E). In both IMCLs and HHSteCs treated with an miR-200b antisense inhibitor, there was reduced expression of selected fibrosis genes (Figure 10). In IMCLs and HHSteCs pretreated with an miR-200b antisense inhibitor and subsequently with $\mathrm{GnRH}$, there was increased expression of selected fibrosis genes (Figure 10); these data demonstrated a direct link between GnRH, miR-200b, and the expression of fibrosis genes.

\section{Discussion}

In the current study, we provide novel evidence that the selective up-regulation of the $\mathrm{GnRH} / \mathrm{GnRHR}_{1}$ axis in cholangiocytes in the $\mathrm{Mdr} 2^{-1-}$ mouse model of PSC and human PSC samples may be a key factor contributing to enhanced autocrine biliary damage and paracrine activation of HSCs, resulting in enhanced liver fibrosis. These findings are also supported by our previous study showing that $\mathrm{GnRH}$ is up-regulated in cholestatic bile duct-ligated rats ${ }^{14}$; however, this study had limitations because we did not observe the up-regulation of GnRHR ${ }_{1}{ }^{14}$ Other studies have demonstrated the expression of GnRH and its receptors in liver, pancreas, and intestine. ${ }^{12,34,35}$ In another cell system, GnRH stimulates the proliferation of other epithelial cells, such as human ovarian cancer cells, by interaction with GnRHR $_{1}{ }^{36}$ Our studies provide the first evidence regarding the role of the $\mathrm{GnRH} / \mathrm{GnRHR}_{1}$ axis in the progression of liver fibrosis in cholestatic liver diseases, including PSC.

A number of studies have shown that the homeostasis of the biliary epithelium is coordinately regulated by a number of neuroendocrine factors, which modulate cholangiocyte proliferation by autocrine/paracrine mechanisms. ${ }^{1,3-6,14,32,37,38}$ There is also growing evidence regarding the role of autocrine/paracrine factors in the modulation of biliary damage and liver fibrosis in PSC. ${ }^{4,10,39-41}$ For example, inhibition of histamine from mast cells decreases biliary hyperplasia and liver fibrosis in $\mathrm{Mdr}^{-/-}$mice. $^{10}$ A recent study has demonstrated up-regulation of the secretin/secretin receptor/TGF- $\beta 1$ axis in Mdr2 ${ }^{-/-}$mice and human PSC samples, and inhibition of the secretin/secretin receptor/TGF- $\beta 1$ axis reduces biliary hyperplasia and liver fibrosis in Mdr2 ${ }^{-/-}$mice. ${ }^{4}$ Also, plateletderived growth factor- $\beta$ has been shown to activate HSCs and induces biliary fibrosis in $\mathrm{Mdr} 2^{-/-}$mice. ${ }^{40}$ Furthermore, blockage of $\beta$-adrenoceptor signaling has been shown to ameliorate liver fibrosis in $\mathrm{Mdr} 2^{-l-}$ mice. ${ }^{39}$ Moreover, absence of the intestinal microbiota has been shown to exacerbate hepatobiliary damage in $\mathrm{Mdr} 2^{-1-}$ mice..$^{41}$ In this context, our study provides novel evidence that the $\mathrm{GnRH} /$ GnRHR $_{1}$ axis may be a new and important target for modulating biliary damage and liver fibrosis in PSC.

To further support the key role of $\mathrm{GnRHR}_{1}$ in modulating $\mathrm{GnRH}$ effects on the biliary epithelium, we demonstrated that 


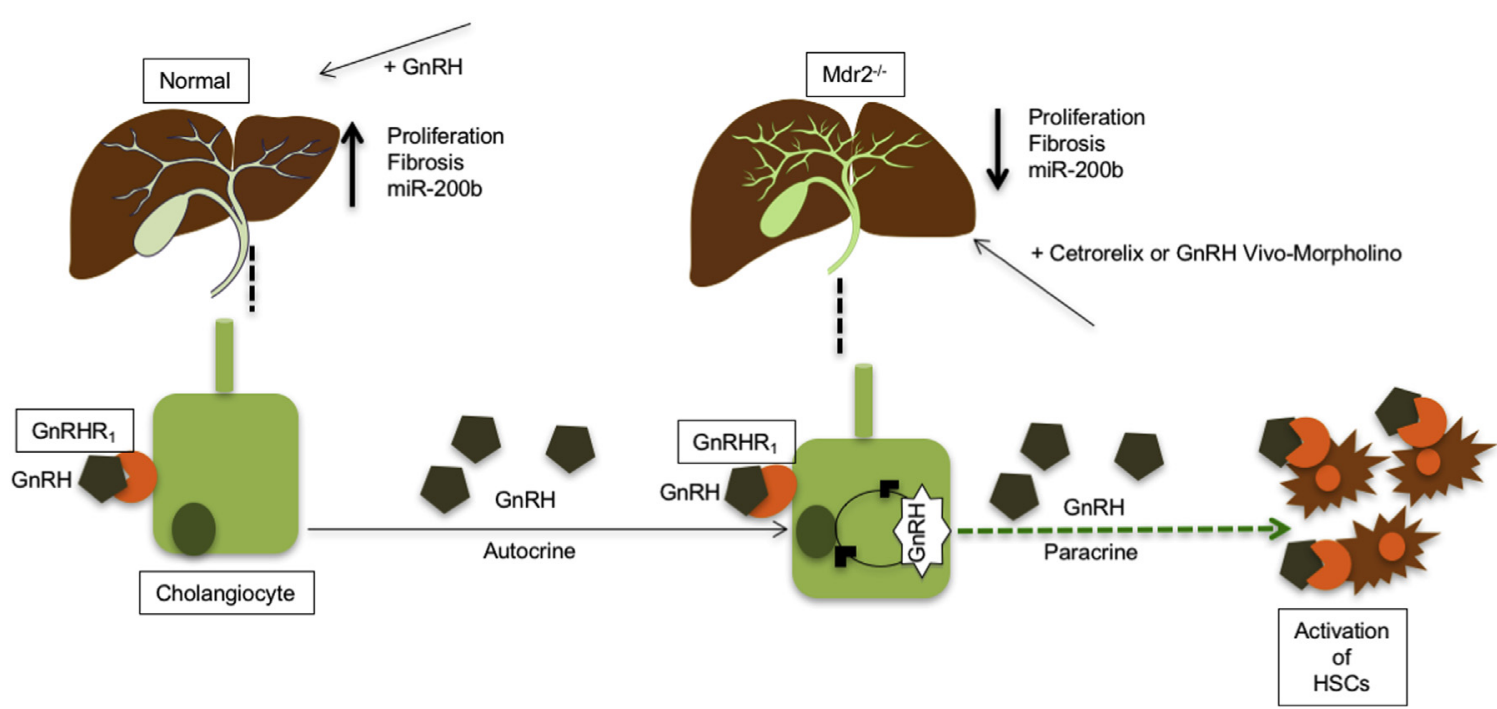

Figure 11 Schematic diagram related to the role of the $\mathrm{GnRH} / \mathrm{GnRHR}_{1} / \mathrm{miR}_{2} 200 \mathrm{~b}$ axis in the progression of liver proliferation and fibrosis. Administration of $\mathrm{GnRH}$ increases biliary proliferation and liver fibrosis through up-regulation of miR-200b. Inhibition of the hepatic expression of the $\mathrm{GnRH} / \mathrm{GnRHR}_{1}$ axis by Vivo-Morpholino or cetrorelix reduces biliary proliferation and liver fibrosis through decreased miR-200b expression.

the type 1 receptor antagonist, cetrorelix, inhibits biliary hyperplasia and liver fibrosis in $\mathrm{Mdr} 2^{-/-}$mice. Although a study has shown that cetrorelix exerts minimal toxicity in the liver, ${ }^{33}$ no studies exist regarding the inhibitory effects of this receptor antagonist on biliary functions and liver damage in PSC. Supporting the antiproliferative properties of cetrorelix, a study has demonstrated that this receptor antagonist inhibits the proliferation of primary cell cultures from human prostate carcinoma. ${ }^{42}$ One clinical study has shown that cetrorelix inhibits the growth of ovarian or mullerian carcinoma in patients refractory to platinum chemotherapy. ${ }^{43}$

Because we demonstrated that cholangiocytes from $\mathrm{Mdr} 2^{-l-}$ mice express and secrete more GnRH compared to WT mice, we performed experiments aimed to reduce the hepatic expression of GnRH as well as biliary proliferation and liver fibrosis. To validate our experimental approach, we first measured the mRNA expression of GnRH in cholangiocytes and HSCs and GnRH levels in cholangiocyte supernatant from the selected groups of animals. The selective increase in both GnRH expression and levels in cholangiocytes as well as serum and total liver samples from PSC patients support the key role of cholangiocytes in the activation of HSCs during the progression of PSC. This finding is supported by our previous study showing enhanced secretion of GnRH at both the basolateral and apical domain of cholangiocytes, ${ }^{14}$ suggesting that proliferating cholangiocytes contribute to liver fibrosis (by an autocrine loop) and a paracrine mechanism by activation of HSCs. ${ }^{4}$

Similar to a previous study showing that intravenous administration of pulsatile GnRH in patients with hypothalamic amenorrhea ameliorates the GnRH secretion from hypothalamus, ${ }^{44}$ we observed a marked increase in GnRH expression/secretion in cholangiocytes, supporting the autocrine role of cholangiocytes in GnRH stimulation of liver fibrosis during PSC. The marginal role of the hypothalamus in regulating biliary damage and liver fibrosis in PSC through secretion of GnRH is also supported by a study demonstrating that hypothalamic-pituitary function is impaired in end-stage nonalcoholic liver diseases. ${ }^{45}$ Furthermore, disturbance in gonadotrophin secretion with inappropriately low levels of luteinizing hormone and follicle-stimulating hormone (whose secretion is regulated by $\mathrm{GnRH}$ ) has been observed in amenorrheic women with alcoholic and nonalcoholic cirrhosis. ${ }^{46}$ In the last sets of experiments, we performed in vitro studies in IMCLs and HHSteCs to demonstrate that the effects of GnRH on biliary proliferation and liver fibrosis are directly mediated by changes in the expression of miR-200b, an miRNA that regulates fibrosis in various tissues, such as liver and kidney. ${ }^{47,48}$ A potential shortcoming of our study is that we did not evaluate the role of the $\mathrm{GnRH} / \mathrm{GnRHR}_{1}$ axis in biliary damage and liver fibrosis in female $\mathrm{Mdr}^{-1-}$ and female PSC samples. However, this is part of another ongoing project. Our findings are summarized in a cartoon (Figure 11) depicting the role of the $\mathrm{GnRH} / \mathrm{GnRHR}_{1} / \mathrm{miR}^{2} 200 \mathrm{~b}$ axis in the progression of biliary proliferation and liver fibrosis. Administration of GnRH increases biliary proliferation and liver fibrosis through up-regulation of miR-200b. Inhibition of the hepatic expression of the $\mathrm{GnRH} / \mathrm{GnRHR}_{1}$ axis by Vivo-Morpholino or cetrorelix reduces biliary proliferation and liver fibrosis through decreased miR-200b expression. In conclusion, our study provides novel insights that the modulation of the $\mathrm{GnRH} / \mathrm{GnRHR}_{1}$ axis and biliary GnRH secretion regulates the progression of liver fibrosis in PSC.

\section{Acknowledgment}

We thank Dr. Ronald A. Faris (Brown University, Providence, RI) for providing the IgM antibody. 


\section{References}

1. Maroni L, Haibo B, Ray D, Zhou T, Wan Y, Meng F, Marzioni M, Alpini G: Functional and structural features of cholangiocytes in health and disease. Cell Mol Gastroenterol Hepatol 2015, 1:368-380

2. Eaton JE, Talwalkar JA, Lazaridis KN, Gores GJ, Lindor KD: Pathogenesis of primary sclerosing cholangitis and advances in diagnosis and management. Gastroenterology 2013, 145:521-536

3. Alvaro D, Mancino MG, Glaser S, Gaudio E, Marzioni M, Francis H, Alpini G: Proliferating cholangiocytes: a neuroendocrine compartment in the diseased liver. Gastroenterology 2007, 132:415-431

4. Wu N, Meng F, Invernizzi P, Bernuzzi F, Venter J, Standeford H, Onori P, Marzioni M, Alvaro D, Franchitto A, Gaudio E, Glaser S, Alpini G: The secretin receptor axis modulates liver fibrosis through changes in TGF- $\beta 1$ biliary secretion. Hepatology 2016, 64:865-879

5. Glaser S, Lam IP, Franchitto A, Gaudio E, Onori P, Chow BK, Wise C, Kopriva S, Venter J, White M, Ueno Y, Dostal D, Carpino G, Mancinelli R, Butler W, Chiasson V, DeMorrow S, Francis H, Alpini G: Knockout of secretin receptor reduces large cholangiocyte hyperplasia in mice with extrahepatic cholestasis induced by bile duct ligation. Hepatology 2010, 52:204-214

6. Glaser S, Meng F, Han Y, Onori P, Chow BK, Francis H, Venter J, McDaniel K, Marzioni M, Invernizzi P, Ueno Y, Lai JM, Huang L, Standeford H, Alvaro D, Gaudio E, Franchitto A, Alpini G: Secretin stimulates biliary cell proliferation by regulating expression of microRNA 125b and microRNA let7a in mice. Gastroenterology 2014, 146:1795-1808

7. Lazaridis KN, LaRusso NF: Primary sclerosing cholangitis. N Engl J Med 2016, 375:1161-1170

8. Fickert P, Fuchsbichler A, Wagner M, Zollner G, Kaser A, Tilg H, Krause R, Lammert F, Langner C, Zatloukal K, Marschall HU, Denk H, Trauner M: Regurgitation of bile acids from leaky bile ducts causes sclerosing cholangitis in Mdr2 (Abcb4) knockout mice. Gastroenterology 2004, 127:261-274

9. Popov Y, Patsenker E, Fickert P, Trauner M, Schuppan D: Mdr2 (Abcb4)-/- mice spontaneously develop severe biliary fibrosis via massive dysregulation of pro- and antifibrogenic genes. J Hepatol 2005, 43:1045-1054

10. Jones H, Hargrove L, Kennedy L, Meng F, Graf-Eaton A, Owens J, Alpini G, Johnson C, Bernuzzi F, Demieville J, DeMorrow S, Invernizzi P, Francis H: Inhibition of mast cell-secreted histamine decreases biliary proliferation and fibrosis in primary sclerosing cholangitis Mdr2 $2^{-/}$mice. Hepatology 2016, 64:1202-1216

11. Wierman ME, Bruder JM, Kepa JK: Regulation of gonadotropinreleasing hormone $(\mathrm{GnRH})$ gene expression in hypothalamic neuronal cells. Cell Mol Neurobiol 1995, 15:79-88

12. Kakar SS, Jennes L: Expression of gonadotropin-releasing hormone and gonadotropin-releasing hormone receptor mRNAs in various nonreproductive human tissues. Cancer Lett 1995, 98:57-62

13. Aguilar-Rojas A, Huerta-Reyes M: Human gonadotropin-releasing hormone receptor-activated cellular functions and signaling pathways in extra-pituitary tissues and cancer cells (Review). Oncol Rep 2009, 22:981-990

14. Ray D, Han Y, Franchitto A, DeMorrow S, Meng F, Venter J, McMillin M, Kennedy L, Francis H, Onori P, Mancinelli R, Gaudio E, Alpini G, Glaser SS: Gonadotropin-releasing hormone stimulates biliary proliferation by paracrine/autocrine mechanisms. Am J Pathol 2015, 185:1061-1072

15. Stewart AJ, Katz AA, Millar RP, Morgan K: Retention and silencing of prepro-GnRH-II and type II GnRH receptor genes in mammals. Neuroendocrinology 2009, 90:416-432

16. Cai Y, Yu X, Hu S, Yu J: A brief review on the mechanisms of miRNA regulation. Genomics Proteomics Bioinformatics 2009, 7: $147-154$

17. Huang Y, Shen XJ, Zou Q, Zhao QL: Biological functions of microRNAs. Bioorg Khim 2010, 36:747-752
18. Korpal M, Lee ES, Hu G, Kang Y: The miR-200 family inhibits epithelial-mesenchymal transition and cancer cell migration by direct targeting of E-cadherin transcriptional repressors ZEB1 and ZEB2. J Biol Chem 2008, 283:14910-14914

19. Lim YY, Wright JA, Attema JL, Gregory PA, Bert AG, Smith E, Thomas D, Lopez AF, Drew PA, Khew-Goodall Y, Goodall GJ Epigenetic modulation of the miR-200 family is associated with transition to a breast cancer stem-cell-like state. J Cell Sci 2013, 126: 2256-2266

20. Sossey-Alaoui K, Bialkowska K, Plow EF: The miR200 family of microRNAs regulates WAVE3-dependent cancer cell invasion. J Biol Chem 2009, 284:33019-33029

21. Xue X, Zhang Y, Zhi Q, Tu M, Xu Y, Sun J, Wei J, Lu Z, Miao Y, Gao W: MiR200-upregulated Vasohibin 2 promotes the malignant transformation of tumors by inducing epithelial-mesenchymal transition in hepatocellular carcinoma. Cell Commun Signal 2014, 12:62

22. Meng F, Henson R, Lang M, Wehbe H, Maheshwari S, Mendell JT, Jiang J, Schmittgen TD, Patel T: Involvement of human micro-RNA in growth and response to chemotherapy in human cholangiocarcinoma cell lines. Gastroenterology 2006, 130:2113-2129

23. Murakami Y, Toyoda H, Tanaka M, Kuroda M, Harada Y, Matsuda F, Tajima A, Kosaka N, Ochiya T, Shimotohno K: The progression of liver fibrosis is related with overexpression of the miR-199 and 200 families. PLoS One 2011, 6:e16081

24. Xiao Y, Wang J, Chen Y, Zhou K, Wen J, Wang Y, Zhou Y, Pan W, Cai W: Up-regulation of miR-200b in biliary atresia patients accelerates proliferation and migration of hepatic stallate cells by activating PI3K/Akt signaling. Cell Signal 2014, 26:925-932

25. Britten JL, Malik M, Levy G, Mendoza M, Catherino WH: Gonadotropin-releasing hormone $(\mathrm{GnRH})$ agonist leuprolide acetate and GnRH antagonist cetrorelix acetate directly inhibit leiomyoma extracellular matrix production. Fertil Steril 2012, 98:1299-1307

26. Glanowska KM, Burger LL, Moenter SM: Development of gonadotropin-releasing hormone secretion and pituitary response. J Neurosci 2014, 34:15060-15069

27. Gibson MJ, Kasowski H, Dobrjansky A: Continuous gonadotropinreleasing hormone infusion stimulates dramatic gonadal development in hypogonadal female mice. Biol Reprod 1994, 50:680-685

28. Shetty G, Wilson G, Huhtaniemi I, Boettger-Tong H, Meistrich ML: Testosterone inhibits spermatogonial differentiation in juvenile spermatogonial depletion mice. Endocrinology 2001, 142: 2789-2795

29. Puche JE, Lee YA, Jiao J, Aloman C, Fiel MI, Munoz U, Kraus T, Lee T, Yee HF Jr, Friedman SL: A novel murine model to deplete hepatic stellate cells uncovers their role in amplifying liver damage in mice. Hepatology 2013, 57:339-350

30. Ueno Y, Alpini G, Yahagi K, Kanno N, Moritoki Y, Fukushima K, Glaser S, LeSage G, Shimosegawa T: Evaluation of differential gene expression by microarray analysis in small and large cholangiocytes isolated from normal mice. Liver Int 2003, 23:449-459

31. Glaser S, Benedetti A, Marucci L, Alvaro D, Baiocchi L, Kanno N, Caligiuri A, Phinizy JL, Chowdury U, Papa E, LeSage G, Alpini G: Gastrin inhibits cholangiocyte growth in bile duct-ligated rats by interaction with cholecystokinin-B/Gastrin receptors via D-myoinositol 1,4,5-triphosphate-, $\mathrm{Ca}(2+)$-, and protein kinase $\mathrm{C}$ alphadependent mechanisms. Hepatology 2000, 32:17-25

32. Li J, Ning G, Duncan SA: Mammalian hepatocyte differentiation requires the transcription factor HNF-4alpha. Genes Dev 2000, 14: 464-474

33. Suszka-Switek A, Czekaj P, Pajak J, Skowronek R, Wrona-Bogus K, Plewka D, Kozlowska-Rup D, Wiaderkiewicz R, Jankowski A: Morphological and enzymatic changes caused by a long-term treatment of female rats with a low dose of gonadoliberin agonist and antagonist. Med Sci Monit 2012, 18:BR315-BR330

34. Zhang J, Huang G, Huang W: [Gonadotropin releasing hormone and its receptor in the tissue of human hepatocellular carcinoma] Chinese. Zhonghua Yi Zue Za Zhi 1998, 78:343-346 
35. Sand E, Bergvall M, Ekblad E, D'Amato M, Ohlsson B: Expression and distribution of $\mathrm{GnRH}, \mathrm{LH}$, and FSH and their receptors in gastrointestinal tract of man and rat. Regul Pept 2013, 187:24-28

36. Grundker C, Emons G: Role of gonadotropin-releasing hormone $(\mathrm{GnRH})$ in ovarian cancer. Reprod Biol Endocrinol 2003, 1:65

37. Alpini G, Glaser S, Ueno Y, Pham L, Podila PV, Caligiuri A, LeSage G, LaRusso NF: Heterogeneity of the proliferative capacity of rat cholangiocytes after bile duct ligation. Am J Physiol Gastrointest Liver Physiol 1998, 274:G767-G775

38. Gaudio E, Barbaro B, Alvaro D, Glaser S, Francis H, Ueno Y, Meininger CJ, Franchitto A, Onori P, Marzioni M, Taffetani S, Fava G, Stoica G, Venter J, Reichenbach R, DeMorrow S, Summers R, Alpini G: Vascular endothelial growth factor stimulates rat cholangiocyte proliferation via an autocrine mechanism. Gastroenterology 2006, 130:1270-1282

39. Strack I, Schulte S, Varnholt H, Schievenbusch S, Tox U, Wendland K, Steffen HM, Drebber U, Dienes HP, Odenthal M: betaAdrenoceptor blockade in sclerosing cholangitis of Mdr2 knockout mice: antifibrotic effects in a model of nonsinusoidal fibrosis. Lab Invest 2011, 91:252-261

40. Yoshida S, Ikenaga N, Liu SB, Peng ZW, Chung J, Sverdlov DY, Miyamoto M, Kim YO, Ogawa S, Arch RH, Schuppan D, Popov Y: Extrahepatic platelet-derived growth factor-beta, delivered by platelets, promotes activation of hepatic stellate cells and biliary fibrosis in mice. Gastroenterology 2014, 147:1378-1392

41. Tabibian JH, O'Hara SP, Trussoni CE, Tietz PS, Splinter PL, Mounajjed T, Hagey LR, LaRusso NF: Absence of the intestinal microbiota exacerbates hepatobiliary disease in a murine model of primary sclerosing cholangitis. Hepatology 2016, 63:185-196

42. Castellon E, Clementi M, Hitschfeld C, Sanchez C, Benitez D, Saenz L, Contreras H, Huidobro C: Effect of leuprolide and cetrorelix on cell growth, apoptosis, and GnRH receptor expression in primary cell cultures from human prostate carcinoma. Cancer Invest 2006, 24 : 261-268

43. Emons G, Grundker C, Gunthert AR, Westphalen S, Kavanagh J, Verschraegen C: GnRH antagonists in the treatment of gynecological and breast cancers. Endocr Relat Cancer 2003, 10:291-299

44. Santoro N, Wierman ME, Filicori M, Waldstreicher J, Crowley WF Jr: Intravenous administration of pulsatile gonadotropin-releasing hormone in hypothalamic amenorrhea: effects of dosage. J Clin Endocrinol Metab 1986, 62:109-116

45. Handelsman DJ, Strasser S, McDonald JA, Conway AJ, McCaughan GW: Hypothalamic-pituitary-testicular function in endstage non-alcoholic liver disease before and after liver transplantation. Clin Endocrinol (Oxf) 1995, 43:331-337

46. Bell H, Raknerud N, Falch JA, Haug E: Inappropriately low levels of gonadotrophins in amenorrhoeic women with alcoholic and nonalcoholic cirrhosis. Eur J Endocrinol 1995, 132:444-449

47. Noetel A, Kwiecinski M, Elfimova N, Huang J, Odenthal M: microRNA are central players in anti- and profibrotic gene regulation during liver fibrosis. Front Physiol 2012, 3:49

48. Vettori S, Gay S, Distler O: Role of microRNAs in fibrosis. Open Rheumatol J 2012, 6:130-139 